\title{
Apuntes para a investigación en lírica profana galego-portuguesa: a figura de Roi Gomez, o Freire, e as súas cantigas ${ }^{1}$
}

\author{
Antonio Fernández Guiadanes / Marina Meléndez Cabo* \\ Universidade de Santiago de Compostela
}

\begin{abstract}
Resumo:
Neste artigo lévase a cabo o establecemento crítico das dúas cantigas de Roi Gomez, o Freire, (B 49 e B 50). Ademais de estudar as particularidades que presenta a rúbrica atributiva que antecede a primeira das súas cantigas, téntase, volvendo ás fontes orixinais documentais, atinar un pouco máis na biografía do autor ligado á primeira xeración trobadoresca.
\end{abstract}

\section{Palavras-chave:}

Edición crítica, lírica profana galego-portuguesa, rúbricas, Roí, Rui, freire, ordes militares, documentación.

\begin{abstract}
:
In this article we will establish critically two cantigas of Roi Gomez, o Freire (B 49 and $B$ 50). With the aim to investigate about this first generation troubadour, we will study the characteristics of the attributive rubric that precedes the first of the pieces, taking as well into account information from documents related to him.
\end{abstract}

Key words:

Critical edition, Galician-Portuguese Lyric, Roí, Rui, Military Oders, documents.

1 Este traballo enmárcase no desenvolvemento do proxecto de investigación Cancioneiros galegoportugueses. Edición crítica e estudo (formato impreso e electrónico) [Proxecto coordinado (USC / UDC / UVIGO). USC: Cancioneiro de Cabaleiros], dirixido por M. Brea e subvencionado pola Xunta de Galicia (PGIDIT06CSC20401PR), con contribución de FEDER. Desde aquí vaia o noso agradecemento a aquelas persoas que leron este artigo e suxeriron ideas que, sen lugar a dúbidas, contribuíron a mellorar a súa forma e contido: M. Brea, M. Ferreiro, D. González, G. del Río e X. Ron. Os erros, evidentemente, son todos nosos.

* Traballo de investigación realizado co apoio dunha bolsa que se engloba no marco do Programa Estatal de Formación de Profesorado Universitario (FPU), financiado polo Ministerio de Ciencia e Innovación - Secretaría de Estado e Investigación. 
Emprender a tarefa de editar criticamente a produción poética dun trobador supón retos e metas moitas veces ben difíciles de acadar. É por isto que as hipóteses que aquí se barallan non pretenden ser máis que conxecturas que en moitos casos non chegarán máis ca a vías sen ou con pouca saída, pero cremos que pode ser interesante poñer a nosa atención en certos aspectos paleo-gráfico-fonéticos, codicolóxicos ou históricos cando se carece doutras informacións contrastables. Toda edición crítica adoita comprender, grosso modo, dúas parcelas ben delimitadas: unha que ten que ver coa figura histórica do autor e outra coa súa obra. Polo que respecta á primeira, sabido é que para moitos dos trobadores son escasos os datos históricos que posuímos e para algúns outros non se dispón de case ningún. No caso de Roi Gomez, o Freire, non temos a certeza de que sexa o personaxe con que o ten identificado a crítica especializada, se ben esta identificación non interesa tanto por saber das súas pertenzas, se casou e tivo "semel" ou se era rico ou pobre, como por coñecer o contexto en que se moveu, as relacións que estableceu ou puido establecer e as persoas con que andou ou puido ter contacto.

Polo que respecta ao segundo dos cometidos, coñecido é por todos que a maior parte das cantigas chegaron ata nós nos apógrafos italianos, e isto quere dicir que a maioría das veces nos enfrontamos cunha lectura "case única", posto que, como códices xemelgos que adoitan ser recoñecidos, as diverxencias entre eles máis ben responden a posibles erros de copia levados a cabo polos amanuenses italianos. Aínda que as dúas lecturas que adoito ofrecen B e V son semellantes ${ }^{2}$, cando non o son poden achegar datos enriquecedores que dean conta do posible erro cometido polo copista de un dos relatores, ou as diferentes lectiones poden proporcionar indicios do que podería haber no antecedente e contribuír a fixar cun maior grao de probabilidade a lectura correcta.

A crítica especializada, ante un manuscrito único, frecuentemente adopta unha actitude que podería considerarse bedierista, isto é, de respecto pola lectura manuscrita a non ser naquelas pasaxes onde se pode apreciar un erro evidente. No noso caso, tentamos levar a cabo, sempre que sexa posible, un establecemento do texto o máis filoloxicamente lexítima posible por medio de dous procedementos que denominamos collatio e emendatio intra- e intertextual (Fernández Guiadanes / Río Riande [no prelo]).

2 Esta lección única (pois procede supostamente dun antecedente común), malia que dobre, que normalmente envían os apógrafos para certas cantigas, por mor das lacunas que afectan a ambos os dous códices, convértese en lectura única dun codex unicus, situación que presenta a produción poética do noso trobador, feito que agrava o labor de edición. 


\section{O autor}

\subsection{A rúbrica atributiva}

Antecedendo a cantiga B 49, A. Colocci escribiu a rúbrica atributiva Rui ¿/? Roy Gomez o Freyre ${ }^{3}$. Na Tavola colocciana ${ }^{4}$ rexístrase o nome Rui uel Roy Gomez o freyre, a carón tamén do número 49. Temos, pois, que, con total seguridade, a barra que puxemos na transcrición cun interrogante da rúbrica de B non é un simple elemento separador de dous nomes senón que está a reflectir a abreviatura do termo latino que o iesino emprega en $\mathrm{C}$ de forma desenvolta. De feito, se observarmos ben esta suposta barra quizais poidamos afirmar que presenta dous trazos, feito que nos leva a pensar nun posible $V$. Abreviatura empregada polo humanista para o termo latino? Cremos que si.

Un tipo de abreviatura similar rexistrámola no Capelli 5 para o termo latino sinónimo (Cappelli 1995: 384).

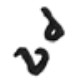

$$
\text { (vd) velud xIv }
$$

O termo latino $u e l$ non aparece só na rúbrica do noso trobador. Rexistramos algúns outros casos nos cancioneiros e na Távola Colocciana:

\begin{tabular}{l|l}
\multicolumn{1}{c|}{ C } & \multicolumn{1}{c}{ B } \\
$\begin{array}{l}\text { 44. Monio uel Nuno Fernandez de } \\
\text { Mirapeyxe }^{6}\end{array}$ & $\begin{array}{l}\text { 44 Monio V Nuno Fernandez [lac.] } \\
\text { irapeyxe }\end{array}$ \\
\hline $\begin{array}{l}\text { 46. Fernan Fig[u]eyra uel Figueyro de } \\
\text { Lemos }\end{array}$ & 46 Fernā Figeyra V Figueyro de Lemos \\
\hline $\begin{array}{l}\text { 74. Don Ferna Paez de Tamalancos } \\
\text { 859. Dom Joham de Meendiz d } \\
\text { briteyros V de berredo }\end{array}$ & $\begin{array}{l}\text { 74. Dom Fernā Paaez V paez de Tamalācos } \\
\text { berre[... }]^{7}\end{array}$ \\
\hline
\end{tabular}

3 M. Barbieri (1993: 584-585) leva a cabo a mesma transcrición ca nós polo que respecta ao elemento que separa as dúas variantes do nome do trobador.

4 Sobre este Índice elaborado por Angelo Colocci, véxase Gonçalves (1976).

5 Millares Carlo (1983, I: 120) na letra carolina ofrece como abreviatura de $v e l=v l$.

6 O trobador, malia non estar documentado, adoita denominarse co nome de Nuno. No caso de Briteyros V Berredo, o trobador é mencionado co apelido familiar do pai e da nai, respectivamente. Monio e Nuno non son variantes gráficas, senón nomes diferentes. Quizais poderiamos pensar nun caso de confusión de Nuno con Munio (variante de Monio) e considerar a posibilidade de que o trobador se chame Monio ou Munio. Para as formas Monio, Munio e Nuno, véxase Boullón Agrelo (1999: 321 e 331).

7 En V esta rúbrica non foi transcrita. A cantiga V 444 está precedida pola rúbrica atributiva Dom Joham meendiz de b $b^{\text {es }}$ ?teyros (quizais por un deficiente desenvolvemento dunha abreviatura b'/ 
O nome do trobador está formado por unha "secuencia antroponímica extensa" (Viejo Fernández 1998: 32) constituída pola "secuencia antroponímica básica ou nuclear": Roí uel Rui Gomez (nome individual mais patronímico), mais a xustaposición dun sobrenome (o Freire). Roí uel Rui son dúas variantes, ambas base curta (ou hipocorístico, segundo Viejo Fernández 1998: 32) da base longa do termo latinizado Ru-/Ro-dericus ou do romance Rodrigo, que son formas frecuentes desde o século XII. En palabras de Rodríguez (1988: 530), o "uso parece querer reservar a forma reduzida para antes do apelido (ou equivalente) e a plena para funçons «substantivas»», e o mesmo opina Menéndez Pidal (1964, I: 206-207). Temos pois que a base curta dos nomes masculinos adoita empregarse diante do apelido, como podemos documentar nas propias rúbricas atributivas dos nosos cancioneiros: Roi Queimado, Men Rodriguez de Briteiros, Fernan Fernandez Cogominho, etc. Interésanos comprobar, en primeiro lugar, como aparece escrito Rodrigo/Roí-Rui nas rúbricas tanto nos cancioneiros B e V coma en C (testemunho externo, segundo Rodríguez 1988: 530), e, en segundo lugar, ver como aparecen escritos os mesmos nomes nas cantigas (testemunho interno, en palabras do mesmo autor).

\footnotetext{
bi ou, menos probablemente, pola confusión co nome do trobador Afonso Mendez de Besteiros). B 858 (o seu correlato) é atribuída a Dom Meen roes de biteyr9 e B 859 presenta, ademais da rúbrica que transcribimos no cadro (rúbrica situada na marxe superior do f. $183 \mathrm{r}$, col. b, onde se copian as cobras II-III da cantiga), outra que precede a primeira cobra: Don? Johā de meēdiz đa biteyro. A atribución das cantigas a cada un dos trobadores en xogo (tanto as deste sector como as do sector de escarnio) parécenos que aínda hoxe en día non está completamente resolta. A persoa que con maior profundidade tentou dar conta desta diverxencia atributiva foi Elsa Gonçalves (1994: 985) que nos di que "em B [no f. 183r] temos três textos, dos quais o primeiro vem precedido da rubrica 'Dom Meen Rodrigues de Briteiros', estando os outros dois sob o nome 'Dom Johan Mendiz de Briteyros', e que em V esiste uma única rubrica, 'Dom Johan Mendiz de Briteiros (sic.?)', para os três". En realidade, no folio en cuestión de B temos tres rúbricas: as dúas de que fala a profesora Gonçalves e outra na marxe superior dereita, da que xa demos conta arriba. Esta última é a única que para o autor rexistra $C$, aínda que debemos destacar que a Távola presenta como unha mestura das dúas rúbricas de B: Johā de Meendiz (da rúbrica que precede a cantiga) e V de berre como a que está na marxe superior. Cal sería o proceso da fusión de dúas rúbricas nunha? Cal será o motivo polo que non aparece tampouco a terceira rúbrica en V? Deberase a un novo lapso de Colocci? Cabe lembrar aquí que a denominación ao grupo familiar dos trobadores aparece en B sempre abreviado como biteyro[s], mentres que en $\mathrm{V}$ aparece desenvolvido e nós cremos que como b ¿es?teyros.
} 


\begin{tabular}{|c|c|c|}
\hline $\mathrm{C}$ & $\mathrm{B}$ & V \\
\hline \multicolumn{3}{|l|}{$\begin{array}{l}31 \text { Don Rodrigo diaz dos } \\
\text { Cameyros }\end{array}$} \\
\hline 250 Roy Queymado & 250 Roy Que ${ }^{y}$ mado & \\
\hline 331 Rodigianes rredondo ${ }^{8}$ & 331 Rodigianes rredondo & \\
\hline 337 Roy paez de ribela & 337 Roy paez de Ribela & \\
\hline $\begin{array}{l}367 \text { Rodigue anes d } \\
\text { Vafcon ¿z? elhos }\end{array}$ & $\begin{array}{l}367 \text { Rodigue Anes de } \\
\text { Vafconzelhos }\end{array}$ & \\
\hline 713 Roy Queymado & 713 Roy queymado & 314 Roy Quey mado ${ }^{11}$ \\
\hline $\begin{array}{l}726 \text { Rodrigue anes de } \\
\text { valit? on cel }{ }^{\mathrm{h}} \text { os }\end{array}$ & 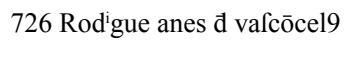 & $\begin{array}{l}327 \text { Rodrigue an̄s de } \\
\text { vafconcel9 }\end{array}$ \\
\hline 899 Roy fernandez de Stiāgo & 899 Roy fernandez de Stiago & 484 Roy fernandiz \\
\hline 926 Roy Fernandez cligo ${ }^{9}$ & 926 Roy Fernādiz cligo & 514 Roy Fernandiz cligo \\
\hline $\begin{array}{l}\text { A } 975 \text { Rodrigue Anes } \\
\text { daluares }\end{array}$ & 975 Rodigue anes Daluares & 562 Rodigue Anes daluares $^{\mathrm{i}}$ \\
\hline 999 Roy Matĭj dulueyra & 999 Roy Mātiis Dulueyra & 588 Roy m̄tijz \\
\hline 1159 Roy Marq $_{z}$ do Cafal & 1159 Roy Marq do casal & 762 Roy MARTIz do Casal \\
\hline 1385 Roy queymado ${ }^{10}$ & 1385 Roy q̄ymado & 994 Roy queymado \\
\hline 1417 Roy paez & 1435 Roy Paez de rribel & 1026 Roy paez de rribela \\
\hline 1440 Roy paez & 1440 Roy paez & 1045 Roy paez de rribela \\
\hline \multirow[t]{2}{*}{$\begin{array}{l}1543 \text { Don Roy Gomez d } \\
\text { bre ¿c?eyro }\end{array}$} & $\begin{array}{l}1543 \text { Don Roy gomez de } \\
\text { breceyr9 fez... }\end{array}$ & 1146 Rodrigean̄s Redondo \\
\hline & Don Roy gomez de breteyros & \\
\hline
\end{tabular}

De todos os trobadores con este nome, dous aparecen coa base longa do nome (Rodrigu' Eanes d' Alvares e Rodrigu' Eanes Redondo) e seis, sen contar o noso, coa base curta (Roi Fernandiz, clerigo de Santiago; Roi Gomez de Briteiros; Roi

8 Gonçalves (1976: p. 410) dá por erro o no 301 para Rodrigu'Eanes Rredondo en vez de 331 como escribe Colocci e como ela mesma reproduce nas leccións do ms., lugar onde ofrece como lectura Rodigeanes onde nós lemos (como en B) Rodigianes (ambos os dous i sen punto).

9 Non concordamos coa descrición que fai Gonçalves (1976: 419) de "cligo con segno abbreviativo sulle prime lettere". Cremos que o signo de abreviatura risca o ele e abranxe varias letras, non só a primeira.

10 Con $y$ corrixido sobre $x$.

11 A rúbrica está situada na marxe superior do f. 51v. 
Martinz do Casal; Roi Martinz d' Ulveira; Roi Paez de Ribela e Roi Queimado). Desta lista de nomes de trobadores -regularizados segundo a LPGP (1996)- a primeira conclusión que podemos extraer é que a base longa do nome se emprega ante vogal (Rodrigu' Eanes) e a base curta ante consoante (Roi Martinz do Casal); isto mesmo acontece, por exemplo, con Fernando e Fernan.

O estudo do testemunho interno da base curta $^{12}$ da palabra Ró́/Rui ${ }^{13}$ revélanos os seguintes datos:

a) A forma Roí rexistrámola en seis cantigas como bisílaba ou monosílaba. No v. 1I (heptasílabo) da cantiga 7,8 "O arraiz de Roí García”, como monosílabo segundo a edición de Lapa 62 (B 1560). No v. 1VI (15 sílabas) da cantiga 16,1 "Ofereceu Trancoso ao Conde Roí Becerro", como bisílabo e acento agudo segundo a edición de Lapa 78 (B 1477, V 1088). No v. 2I (decasílabo) da cantiga 32,114 “a Roí Paáez, logo este dia", como bisílabo e acento agudo segundo a edición de Lapa 128 (B 1611, V 1144). No v. 1I (decasílabo) da cantiga 125,45 "Roy [Q]ueimado morreu con amor", como bisílabo segundo a edición de Blasco 47 (B 1380, V 988). No v. 5III (heptasílabo) da cantiga 127,5 "que Roí Gómez de Telha”, como bisílabo e acento agudo segundo a edición de Lapa 394 (B 1445, V 1056). Na cantiga 152,715 nos vv. 3II "eno forniz[io] é don Roi Gil”, 4II "e Roi Martiiz ena falsidade” e 5IV "con Roi Gil; e meus preitos talhei", como bisílabos na edición de Arias Freixedo 228 e bisílabos e con acento agudo en Lapa 423 (V 1020).

b) A forma Rui aparece en dúas cantigas. A primeira delas é a 30,31 de Estevan da Guarda, v. 1I "Rui Gonçalviz, pero vos agravece", como monosílabo na edición de

12 A regra cúmprese para Rodrigo e a base longa úsase cando vai soa ou con apelido diante de vogal no v. 1I de 18,17 "Don Rodrigo moordomo que ben pos al Rei a mesa" (malia que na mesma cantiga non se cumpra no v. 1III "Levarei Fernando Telles con gran peça de peões", por exemplo); no v. 1II da cantiga 46,4 "Rodrig' Airas vo-lo diss' e fez mal sén"; no v. 2I da cantiga 61,1 "de casa de Don Rodrigo"; no v. 2I da cantiga 87,15 "Rodrigo polo matar"; nos vv. 2I, II da cantiga 87,19 "por teu cantar iá Rodrigo perdi” e “perdi Rodrigu' e non o poss' achar”, respectivamente; nos vv. 1I, III e 1I fiinda da cantiga "Rodrigu' Ianes, queria saber", "Rodrigu' Eanes, sempr' eu loarey" e "Rodrigu' Ianes, hu meu cantar for", respectivamente; no v. 5 refrán da cantiga 139,1 "Rodrig' Eanes d' Alvares é tal" e no v. 6 IV da cantiga 152,7 “con frei Rodrigu', e mentiu-mi-os; e sei”.

13 Falando do Cid Campeador dinos Menéndez Pidal (1964, I: 170) que con toda a probabilidade o autor "diría «Ro-y» (...) que suponemos bisílabo (...), y en cuanto al acento, no podemos propiamente hablar de él, pues esta forma es únicamente usada en proclisis, pero si le supusiésemos un acento secundario, lo supondríamos en la $i$, como el moderno apellido «Ruíz»”.

14 No íncipit da cantiga, o nome propio Estevan aparece coa base curta (Estev') diante do apelido Eanes comezado por vogal, fronte á forma longa Estêvão (en 16,$5 ; 16,6 ; 16,7 ; 101,2)$ e Estevan $(79,17$; $79,18 ; 116,8 ; 148,7 ; 148,8)$, cando aparece só, ou a forma Estevan da Guarda $(30,35)$.

15 Na cantiga faise referencia á orde do Hospital e a un frei Rodrigo (v. 6IV), que aparece na súa forma longa posto que non aparece o apelido. 
Arias Freixedo 237 e monosílabo e con acento agudo en Lapa 112 (B1312, V 917). A outra cantiga é, segundo a rúbrica explicativa que a precede en $\mathrm{V}$, unha tensó de que só se conservaron cinco versos; nela, o nome Rui aparece nos v. 1 "Rui Martĩiz, pois que est' [é] assi" e v. 5 "Rui Martĩiz, assi Deus vos perdon”, como monosílabo na edición de Rodríguez (1980: 316) e Lapa 179.

\subsection{Unha hipótese sobre o personaxe e o seu contexto histórico}

De homónimos do noso trobador sen o sobrenome o Freire está inzada a documentación medieval. Xa nos propios cancioneiros temos un homónimo, o fillo e neto de trobadores, Roi Gomez de Briteiros ${ }^{16}$. A investigación levada a cabo por C. Michaëlis (1990, II: 529) abarcara dúas vías: localizar entre os "Ruy Gomes (de Trastámara, de Briteiros, Azevedo, Basto, etc.) este Freire, e entre os Freires de Santiago, do Templo, e dos Hospitaleiros um Ruy Gomes; mas sem resultado". A estudosa enunciaba a posibilidade de que este Roi Gomes fose un fidalgo, cun alcume Freire ben significativo, un dos señores do castelo de Andrada de quen descenden os Freire de Andrada. Desta familia afirma a estudosa que procederon notables personaxes en Portugal e España, e entre eles cóntanse "mais de um Ruy Gomes e varios freires que esqueceron os solemnes votos feitos ante o altar, deixando fructos dos seus amores". Para Resende de Oliveira (1994: 432) a presenza do artigo $o$ antes do patronímico Freire suxire que non fai referencia ao nome de familia, senón a un personaxe que tería pertencido a algunha das ordes militares implantadas na Penísula Ibérica a partir do século XII. Seguindo este camiño, o investigador portugués acha "Rodrigo Gomes, freire da ordem de Avis, que testemunha a doação, pela rainha D. Mafalda, filha de D. Sancho I, dos seus bens en Seia à mesma ordem en 1215". Oliveira tira o dato de J. A. de Figueiredo, quen remite a este documento de doazón de 1215 onde se recolle como a raíña ${ }^{17}$ lle doa estes bens a "D. Fernando Annes, Magistro Ordinis de Avis" (2003, II: 231). Segue describindo Figueiredo que para "testemunho, e perpetua memoria do que lhe fez fazer a referida Carta, e sella-la com o seu sello, que ainda conserva de cêra vernelha, pendente por cordão de seda da mesma cor"18 (2003, II: 232) e acaba concluíndo que "foram presentes D. Gonçalo Annes frater Ordinis Calatrauen, Fr. Hylario, e Rodrigo Gomes fratres eiusdem Ordinis, e outros: Gonsalvus peraria et

16 E non está de máis recordar que o mesmo nome levaba un dos personaxes máis influente da época, Roi Gomez de Trastámara.

17 Dona Mafalda ostentaba o título de raíña porque seu pai así o dispuxera, pero en realidade o rei era seu irmán Afonso II.

18 A carta de doazón atópase en Lisboa no Arquivo Nacional da Torre do Tombo: IAN/TT, Ordem de Avis, maço $2, \mathrm{n}^{\circ} 74$. 
Joannes abbas, et Laurentius Garcie homines de creatione domine Regine testes"19 (2003, II: 232).

No documento orixinal observamos tres filas de testemuñas, e é nas dúas primeiras liñas onde aparecen os tres membros da Orde de Calatrava:

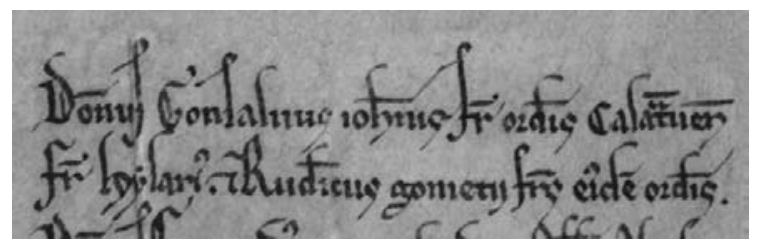

O primeiro que debemos advertir é que, segundo o testemuño da carta de doazón, Roi Gomez sería freire da orde de Calatrava, da cal era filial a portuguesa Orde de Avis ${ }^{20}$, orde con que o identificara Resende de Oliveira. A adscrición deste Roi Gomez á orde de Avis quizais nos fixese identificalo cun portugués, mais a adscrición directa á orde castelá de Calatrava fixo que tivésemos as nosas dúbidas. Foi por iso que tentamos pescudar nos personaxes que aparecen no documento ao seu carón. Pola nosa parte, a identificación de Gonçalo Eanes co personaxe galego Gonzalo Eanes de Novoa parte da lectura de Mattoso e Sousa (1993: 109). Ademais de referir que este personaxe foi "grão-mestre" da orde de Calatrava entre 1218-1238, dinos que foi irmán dun Pero Eanes que ocupou o cargo de mordomo-mor de Afonso II. Ambos eran fillos de Joan Airas (personaxe influente na corte de Afonso IX de León) e Urraca Fernandez (filla

19 Ver mosteiro Arouca doc. 229, con firmas de Calatrava e do Hospital.

20 Nesta nota seguimos a Ayala Martínez (2003: 89-91). A Orde de Avis tivo a súa xénese na milicia de Évora, milicia de que se ten noticia en 1176 e que estaba adscrita á regra beneditina. Nun momento anterior a 1187, a milicia evorense abandonou a súa adscrición primitiva cluniacense e asociouse á orde castelá de Calatrava. En maio de 1201 o papa Inocencio III toma baixo a súa protección a milicia portuguesa, feito que leva a afirmar ao investigador con toda a probabilidade a profesión dos seus membros baixo a orde castelá. A súa consolidación levarase a cabo tras a percepción da fortaleza de Avis en 1211, época de ambiente totalmente cruzadista e un ano antes da batalla das Navas de Tolosa. Este último dato ofrecéunolo tamén o profesor Resende de Oliveira vía e-mail (a quen lle mostramos a nosa gratitude e lle agradecemos a súa dispoñibilidade) e acrecentou que "Na inscrição da fundação do castelo de Avis (1214) pode ler-se (em tradução a partir do latim): Fernando, pela graça de Deus mestre da ordem de Calatrava em Portugal, com o seu convento, implantou Avis na festa da Assunção de Santa Maria". O documento de 1215, uma doação da D. Mafalda à Ordem de Calatrava/Avis, integra-se num contexto de conflito entre o rei português D. Afonso II e suas irmãs Mafalda, Teresa e Sancha em virtude dos senhorios que lhes tinham sido deixados pelo pai D. Sancho I. É interessante verificar que os Sousas se colocaram do lado das irmãs do rei tendo sido obrigados a exilar-se em Leão, onde D. Garcia Mendes aparece a compor". 
de Fernan Perez de Traba). Ademais destes dous fillos, o matrimonio tivo dous varóns máis: Osoiro -supostamente o tamén trobador, véxase Frateschi Vieira (1999: 146); Monteagudo (2008: 325-327); Souto Cabo (no prelo)-e Arias.

O outro dos personaxes que aparece na carta de doazón, Hilario, documéntao Souto Cabo (no prelo) en 1222 como o "autor material" da carta de cesión do mosteiro de Armeneses á condesa $\mathrm{D}^{\mathrm{a}}$ Sancha e noutro documento do mesmo ano como "Hilarius, notarius domini G. Iohannes". Deste personaxe di no seu artigo:

Desconhecemos qual foi a naturalidade do notário, mas o vínculo com Gonçalo Eanes convida a pensar que foi galego e possivelmente da área em que os Novoa concentravam uma parte do seu património. De facto, poderá ser identificado com a personagem homónima que, ao menos, entre 1193 e 1197, lavra diversos diplomas do núcleo documental de Oseira e da Catedral de Ourense. A grande singularidadde do antropónimo e a coincidência na actividade escribal apoiam a identificación proposta (Souto Cabo [no prelo]).

Nun documento de setembro de 1223 (Cruz 1988: 363-364), o mestre da orde de Pereiro e Alcántara, orde filial de Calatrava, Garcia Sanchez (1219-1227, segundo Ayala Martínez 2003: 851) dóalle a Ouroana Peres (ama de Da Mafalda) unha herdade do patrimonio do seu irmán freire Pedro Peres. No documento están presentes tamén Gonçalo Eanes (agora xa "maioris magistri) e "frater Ylarius presbiter et milites domnus Sancius". Se o Hilario aquí mencionado é o mesmo que aparece no documento de 1215 e no de 1222 debemos concluír que entre as ordes dependentes de Calatrava había certa mobilidade de persoas e de cargos $^{21}$. Do mesmo xeito, na obra de Rades y Andrada (1980: folio 34v) dísenos que o noveno "maestre" foi “Gonçalo Yañez" e advírtenos que

en otras escripturas se dize don Gonçalo Ioan, y en Latin Gundisaluus Ioannis: mas todo es vn sobrenombre, y assi no son differẽtes Maestres como algunos piensan. Fue hijo de Ioan Arias de Noboa, Cauallero principal de Galizia: y antes que tomasse el Habito desta Orden, fue casado con doña Maria Fernandez, hija de Conde don fernan Perez de Traua, $\overline{\mathrm{q}}$ fue gran señor en Galizia. Tuuo en esta señora vn hijo que llamo Suero Paez, de quien descienden los Valladares.

En conclusión, a principios do século XIII, concretamente en 1215, documentamos un Rodrigo Gomes, freire da Orde de Avís, que participa como testemuña nunha

21 Sería ben lembrar aquí, por exemplo, que en 1215 Gonçal' Eanes era un freire de Calatrava que daba fe nun documento quizais cando xa ocupaba o cargo de comendador maior da orde durante o mandato de Martin Fernandez de Quintana (mestre entre 1216-1218, segundo Rades y Andrada 1980: f. 34), mestre entre 1215-1218 (Ayala Martínez 2003: 848), de ser certa a data que baralla este último investigador. 
doazón. Non obstante, hai que seguir pescudando na documentación e ter en conta a posibilidade de cambio de orde e, incluso, de estado civil e de profesión. Quizais novas pesquisas ou novas edicións documentais nos fagan confirmar ou non que estamos perante o personaxe histórico que compón cantigas e que aparece no documento da Torre do Tombo.

\section{A produción poética}

\subsection{A transmisión manuscrita}

A produción poética de Roi Gomez está constituída por dúas cantigas de amor (B 49-50) que só foron transmitidas polo Cancioneiro da Biblioteca Nacional -tamén coñecido como Colocci-Brancuti-, correctamente colocadas na parte inicial da primeira sección ${ }^{22}$, é dicir, a que correspondería ás cantigas de amor na distribución primitiva, situadas entre D. Gil Sanchez e Fernan Rodriguez de Calheiros. Este cancioneiro convértese, así, en codex unicus para estes textos, posto que en V existe unha gran lacuna inicial. Resende de Oliveira (1994: 6466) asignoulle o $n^{\circ} 15$ no seu cadro xeral de trobadores e sostén que o trobador se sitúa "numa zona onde estão agrupados os autores mais antigos, isto é, de finais do séc. XII e primeira metade do séc. XIII", polo que debe ter desenvolvido a súa actividade poética na primeira metade do XIII, aínda que, como afirma o historiador portugués, "teremos que esperar para uma identificação que confirme a antigüidade da sua colocação".

Os textos do trobador comezan a copiarse en B no f. 16r, col. $a$, como xa dixemos, baixo a rúbrica atributiva de man do iesino Rui uel Roy Gomez o Freyre, que é o responsable, xunto co copista $a$, da transcrición de case todas as rúbricas atributivas neste códice. Reprodúcense a seguir as dúas cantigas numeradas por Colocci (textos 49 -corrixido sobre 48- e 50), que culminan no f. 16v, ao final da col. a, xa que na $b$ se inicia a copia das cantigas de Fernan Rodriguez de Calheiros, como sinala a rúbrica atributiva do humanista italiano.

As cantigas están inseridas no fascículo 3 (ff. 16r. a/b - 16v. a), un quiñón regular transcrito pola man que Ferrari (1979: 27-142) identificou coa letra $c$ e que, segundo a autora, "procede per settori compatti (fasc. 21-22) e per fascicoli (fasc. 3 e 40)" (1979: 84), con varias intervencións máis en cadernos en que alterna con outros

22 Segundo Resende (1994: 169), esta parte correspóndese co primeiro nivel de formación do Cancioneiro, isto é, aquela destinada "aos trovadores mais antigos, isto é, àqueles que iniciaram ou poderão ter iniciado a sua actividade cultural nos fins do séc. XII ou, mais seguramente, no primeiro quartel do século seguinte". 
amanuenses. A respecto da súa letra, a man $c$ emprega a letra gótica bastarda, seguramente "di provenienza francese", mais é de salientar "la $-\mathrm{s}$ finale di $c$ non bastarda: forse un tentativo mimetico di italianizzazione?" (1979: 86).

\subsection{Caracterización formal}

As dúas cantigas de amor responden ás normas conceptuais codificadas na tradición cortés, mais os poemas ofrecen unha peculiar elaboración métrico-formal que compensa, en certo sentido, o carácter convencional dos contidos transmitidos nos seus enunciados. Así, comprobamos que os esquemas estróficos empregados por Roi Gomez son orixinais con respecto á escola galego-portuguesa: a cantiga Oimais non sei, mia senhor $(149,1)$ presenta un esquema rimático abbaccdd, en versos octosílabos, que é unhas das fórmulas estróficas máis frecuentes na poética provenzal. Neste sentido, Beltrán (1995) destaca que os provenzais "preferían as estrofas amplas e complicadas, para as que adoitaba esixirse un mínimo de catro rimas distintas", mais na escola galego-portuguesa cantigas con estes esquemas resultan moi raros e "debemos entender que é, paradoxalmente, por complexas de máis". Isto podería explicar o feito de que no corpus lírico galego-portugués o tipo abbaccdd tan só fose empregado, ademais da cantiga de Roi Gomez, na cantiga do trobador Pero Garcia Burgalês, Mentre non soube por min mia sennor $(125,22)$, na de Pero da Ponte, Nostro Senhor Deus! ¿Que prol ten ora $(120,28)$, na cantiga Pois que vos eu quero mui gran ben de Men Rodriguez Tenorio, e, finalmente, na composición Sazon é ja de me partir $(111,7)$ de Osoir' Anes, que Monteagudo (2008: 361-362) relaciona coa cantiga Nuls hom no pot d'amor gaudir, do trobador occitano Peire Vidal, xa que esta ofrece tres palabras en rima comúns coa de Osoir' Anes ${ }^{23}$.

Do mesmo xeito, a cantiga Pois eu d'atal ventura, mia senhor $(149,2)$ emprega o esquema rimático $a b b a c c d d b$, único no corpus da lírica galego-portuguesa. Por outra parte, ambas as cantigas son de mestría e están articuladas en cobras dobras ${ }^{24}$, a primeira formada por catro cobras de 8 versos todos eles octasílabos agudos, mentres que a segunda presenta catro cobras de 9 versos decasílabos agudos con unha finda de cinco versos de igual medida.

23 Monteagudo (2008: 362) insiste, neste sentido, nun contacto directo entre Osoir' Anes e Peire Vidal durante a visita do segundo á corte de Afonso IX, entre 1201 e 1204, coincidindo co breve período de convivencia matrimonial de Berenguela de Castela e Afonso de León, que durou desde 1199 ate 1204. Recordemos que Roi Gomez é situado nunha posición moi alta en $B$, como xa comentamos, separado de Osoir' Anes unicamente por tres autores. Sobre a presenza de Peire Vidal na Península e a súa influencia véxase Avalle (1960), Alvar (1978: 235-242) e Miranda (2004: 63-77).

24 Para un estudo sobre este tipo de ligazón interestrófica, véxase Correia (1995: 75-90). 
Táboa de esquemas estróficos

\begin{tabular}{c|l|c} 
Tavani & \multicolumn{1}{|c|}{ Esquema estrófico } & Cantiga \\
\hline $168: 7$ & $8 \mathrm{a} 8 \mathrm{~b} 8 \mathrm{~b} 8 \mathrm{a} 8 \mathrm{c} 8 \mathrm{c} 8 \mathrm{~d} 8 \mathrm{~d}$ & II \\
\hline $169: 1$ & $10 \mathrm{a} 10 \mathrm{~b} 10 \mathrm{~b} 10 \mathrm{a} 10 \mathrm{c} 10 \mathrm{c} 10 \mathrm{~d} 10 \mathrm{~d} 10 \mathrm{~b}$ & I \\
\hline
\end{tabular}

Cun corpus tan reducido como o de Roi Gomez pouco se pode deducir da lingua utilizada; non obstante é de salientar que, por un lado, presenta un léxico e unhas estruturas semellantes ás da maioría dos trobadores, mais, por outro, non podemos deixar de sinalar o emprego, na cantiga Pois eu d'atal ventura, mia senhor (149,2), de provenzalismos tales como ben lheu / leu e greu (para os seus valores, véxase García-Sabell Tormo 1991: 175-179 e 203-205) e da forma verbal endurar, xa que, segundo M. Brea (2005: 527-539), o termo rexístrase en 25 cantigas do corpus lírico galego-portugués atribuídas a un total de 18 trobadores cunha actividade literaria que se sitúa maioritariamente entre o segundo e o terceiro cuartos do século XIII. Deste xeito, tanto a súa posición en $\mathrm{B}$ como a ocorrencia deste conxunto de formas nun corpus tan breve apunta con forza para unha cronoloxía recuada -quizais na primeira metade do século XIII-. Neste sentido, Monteagudo (2008: 391-392), que leva a cabo un estudo acerca das características xerais do núcleo trobadoresco inicial, sinala:

(...) a existencia dun círculo de autores que inclúe no cerne a Osoyro Anes, Fernan Rodriguez de Calleyros e Johan Soayrez Somesso, e máis ou menos estreitamente vencellados a algún dos tres, tamén a Ayras Moniz d' Asma e Roy Gomez (conectados con Osoyro Anes), Vasco Praga de Sandin (ligado polo menos a Calleyros e Somesso) e Fernan Paez de Tamallancos. (...) O dito grupo debeu ter como centro cohesionador unha corte nobiliar (ou varias) do centro-sur de Galicia, quizais a dos Limia, e varios membros del estreitaron contactos con cortes nobiliarias do Portugal setentrional (Somesso, Sandin). Igualmente, puideron frecuentar a corte de Afonso IX, e se cadra algunha outra (Fernando III?)

\section{Criterios de edición}

A seguinte proposta de edición ten como base o Cancioneiro da Biblioteca Nacional, mais tivéronse tamén en conta todas as edicións precedentes de cada unha das cantigas. A reprodución dos textos respecta a orde que para os mesmos ofrece o apógrafo italiano. 
Canto ás normas de edición optamos polas aprobadas na reunión científica que, patrocinada pola Consellaría de Cultura da Xunta de Galicia, se celebrou na Illa de San Simón en xuño de 2006, organizada polo Grupo de Investigación de Lingüística Histórica e de Ecdótica (GUILHADE), da Universidade da Coruña, e en cuxa elaboración participaron investigadores das tres universidades galegas ${ }^{25}$.

\section{Texto crítico}

\subsection{Pois eu d'atal ventura, mia senhor}

B 49, f. 16r, cols. a-b

Tavani, 149, 2

Pois eu d' atal ventura, mia senhor, contra vós sõ[o] que non ei poder de falar con vosc' e vos entender; non creedes ca vos quer' eu melhor

5 de quantas cousas [e]no mundo son: senhor fremosa, mui de coraçon me prazeria morrer, e pois ei sen vosso ben, que sempre desejei des que vos vi, en tal coit' a viver,

10 en qual eu vivo por vós, que maior sabor avedes de me non fazer ben, mia senhor, e de me mal querer ca se vos eu oesse desamor, mia senhor fremosa, que vos eu non

15 averei nunca nen ũa sazon, e quant' eu máis viver tant' averei maior amor de vos servir, ca sei que ja por al non ei coit' a perder, senon por vós, mia senhor; se nembrar 20 vos quiserdes de min, que outra ren non sei no mundo querer tan gran ben com' a vós quer', e par Deus, se me dar

25 Ferreiro, M. / Martínez Pereiro, C. P. / Tato Fontaíña, L. (eds.) (2007). Tamén están dispoñibles en http://www.udc.es/publicaciones/ga/libreriaDixital.htm 
quiser mia morte que m' ei mui mester, pois me de vós, mia senhor, dar non quer

25 ben, a que Deus tan muito de ben deu, non por meu ben, mia senhor, mais por meu mal, pois por vós tanto [de] mal me vén

quand' eu non ei ja poder d' endurar, mia senhor fremosa, per nen un sén,

30 se vosso desamor, que m' ora ten forçado, non fezerdes obridar; ca mentr' eu vosso desamor oer, com' oj' eu ei, m[ia senhor, e] tever vosco tan mal mia fazenda com' eu

35 tenho con vosco, non [me será] greu de morrer, e prazer-mi-á máis én

ca de viver, pois í a vós fezer prazer e min de gran coita poder guardar, e vós nembrar-vos-á ben lheu assi de min, como se sol do seu omen nembrar, depois sa mort', alguen.

Edición crítica colectiva de Michaëlis (1990: 333; 665-666).

Edición semidiplomática e interpretativa Molteni (1880: 23; 15); Machado (1949-1964, I: 23; 64-66).

Antoloxía Arias (2003: 270-273).

2. sõo] fon B 6. coraçon] coracon B 14. non] mon B 19. mia senhor] senhor minha B 22. quer'eu] querer B 33. ey $m$ [lac.] or teuer B 35. nõ [lac.] greu B 36. prazer-mi-á] praz'nna B 39. nembrar vos] nẽbraqu9 B 40. de min] demuj B.

1. Poys; uentura; mha 2. uos; eý 3. uofque, u9 4. u9; queren 6. muj; 7. moirer; epoys ey 9. defqueu9; uj; coyta; uiueR 10. Em; q̃l; uýuo; uos; $\bar{q}$; maýor 11. auedes; 12. bē; mha; q̄rer 13. feu9 14. mha; qu9 15. ausey; nū ca; nē; hūa 16. q̃teu; mays; uiuer; tātauerey 17. mayor; deu9; feruir; fey $\mathbf{1 8 .}$ ia; nō; ey; coyta 19. Senō; uos; nēbrar 20. uos; qiferdes; demj; $\bar{q} ;$ rem 21. nō; fey; mūdo; q̄rer; tam; gram 22. comauos; querer; đs 23. qif; mha; $\bar{q}$; mey; muj 24. poyfme; deuos; mha; nō; q̄r 25. bē; $\bar{q}$; de9; tâ; muyto 26. nō; ${ }^{\text {r } ; ~ b e ̄ ; ~ m h a ~}$ fenh ${ }^{\text {r }}$; mays; $p^{r}$ 27. poys; $p^{\text {r; }}$ uos; tāto; uen 28. nō; eý; ia; 29. mha; fenh ${ }^{\text {r } ; ~ p ; ~ n e ̄ ; ~}$ 
hū 30. uoflo; $\bar{q}$; 31. nō 32. ment $^{\uparrow}$ u; uollo 33. comoieu; ey; teuer 34. uofco; tā; mha; fazēda; 35. cō; uofco; nō 36. mays 37. uiưं; poys; hi; auos 38. emj̄; gm; coyta 39. euos 40. afly 41. homē; nēbrar; depoys.

\section{Sinopse retórico-formal}

Cantiga de amor do tipo de mestría integrada por catro cobras dobras (b I, II = e) de 9 versos decasílabos agudos mais unha fiinda de cinco versos tamén decasílabos agudos $[9+1 \mathrm{f}(5)]$. O número de esquema métrico que lle outorga Tavani á composición é 169:1 (10a10b10b 10a10c10c10d10d10b); e, para a fiinda, 10e10e10d10d10b-sobre III-IV-).

\section{Notas aos versos}

2. A lección do apógrafo italiano, na forma que nos chegou, transmite un verso hipómetro: contra uos fon que non ey poder, que, malia que podería desde unha perspectiva actual ter sentido tanto desde o punto de vista semántico coma sintáctico, preferimos corrixir tendo en conta a falta dunha sílaba. Para resolver a falta desta sílaba, Michaëlis, e despois Arias, emendan o verso nas súas respectivas edicións transformando a forma verbal fon en sõo. A forma sõo documéntase nos textos medievais ao lado da forma regular para a $1^{\text {a }}$ persoa do presente, son, derivada da forma latina SUM. Nesta evolución debeu influír a analoxía coa mesma persoa e tempo doutros verbos, engadíndose a son o morfema de número-persoa: - o. Para o presente de indicativo do verbo ser existían en galego-portugués outras formas derivadas dunha base * SONO, que deu como resultado as formas medievais como sõo, soo e sou; esta última aínda pervive dialectalmente en galego, xunto coas formas soio e seño (Azevedo 1986: 814-816; Ferreiro 1995: 337). En A todos os casos de son (verbo) responden á terceira persoa do plural; pola contra, todas as primeiras persoas do verbo ser responden ás diferentes formas bisílabas coas súas distintas representacións gráfico-fonéticas: soo (sete casos), sõo (catorce casos), sõon (un caso: A 43), soon (un caso, A 37) soõ (tres casos: A 136 -un- e A 206 -dous-). Tanto en B coma en $\mathrm{V}$ podemos achar a alternancia, nunha mesma cantiga, da forma regular son xunto coas formas soo e sõo. A alternancia de ambas as formas dáse en cantigas como a 7,4 de Afonso Mendez de Besteiros "vedes que fez ena guerra -daquesto soo certão" (v. 2I) fronte a "vedes que fez ena guerra -daquesto son verdadeiro" (v. 2II); 111,3 de Osoir' Anes "De muitos son preguntado" (v. 1III) fronte a "pero sõo mais folgado" (v. 3IV); 149,2. Deste xeito, o emprego dunha ou doutra forma por parte dalgún dos trobadores parecía depender, na maioría dos casos, de cuestións puramente métricas. Finalmente, segundo Correia (2001: 274), a preposición contra “(...) estabelece uma relação entre dois elementos, normalmente 
de oposição, quer seja material (diante de, em direcção a) quer seja moral (em oposição)". Para o valor de contra co valor de 'con relación a', 'respecto a' usado nesta cantiga, véxase tamén Rodríguez (1980: 212 e 340).

3-4. Tanto Michaëlis coma Arias Freixedo consideran que no v. 4 a lección creedes sería un erro por queredes. Non obstante, Machado mantén a lectura do apógrafo e edita: de falar conuosqu e uos entender, / non creedes que uos quer eu melhor. Ao manter a lección do manuscrito fica obrigado a situar a vírgula despois do verbo entender, interpretando que o trobador non ten poder para falar coa senhor e para entendela xa que esta non cre que a queira mellor que todas as cousas que hai no mundo. Monaci (1880: XXVII) na súa "Tavola dei principali errori" presenta un apartado en que recolle o paso de $c r$ a $q$ : V 14, v. 6, qeo por creo (B $403^{\text {bis }}$ copista $d^{26}$; V 55, v. 10 qeer por $\operatorname{creer}$ (B 443 copista $d^{27}$; A 213 creer); V 61 vv. 7-8 qee / demora por creedemora (B 478 só copia o primeiro verso); e V 316, v. 15, queerey por creerey (B 715 creerey, copista $d$ ). Monaci non localiza os erros contrarios, isto é, o paso que a cre. De estarmos ante un erro, como se desprende das edicións dos tres investigadores, deberiamos supoñer nas ramas altas da tradición manuscrita un *queredes (que na lectura da perícopa o copista pasou a creedes porque tiña preto un quero: "entender / non queredes ca vos quereu melhor"), un *q̄redes (onde desbotou unha abreviatura ou non a percibiu, e onde supuxo un $\mathrm{cr}$-con erre longoe un erre que transformou en $e$ ), ou mesmo un qredes (na que teriamos en conta os dous últimos pasos do caso anterior). Calquera das posibilidades poderían ser válidas e seguramente algún exemplo podemos achar, mais o noso coñecemento dos textos manuscritos, ata o de agora, non nos proporcionou ningún. É por isto que, antes de aceptar sen máis emendas dos editores anteriores, debemos tentar dar unha explicación ao que hai no códice, malia que cheguemos á conclusión de que o que alí se transmite non é máis ca un erro. Segundo se desprende da edición dos autores antes citados, parece que para eles estes versos coa lección creedes carecen de sentido. Consideran que na segunda parte do v. 3 "e vós entender / non queredes ca vos quer' eu melhor” constitúe unha oración unida á anterior mediante a conxunción copulativa $e$. Tal como eles editan o texto, este é correcto desde un punto de vista do significado e da métrica. Por unha banda, o infinitivo entender como complemento directo do verbo querer non o documentamos no corpus profano nunha estrutura de primeiro grao dun suxeito receptor (a amada) que non quere ser consciente de

26 O copista non debía ter claro que transcribir: pretendía escribir $c r$, con erre longo, e non estando seguro da lección tratou de transformalo nun $q$ ? No verso anterior reproduce dous erres longos en rrapaz.

27 No v. 17 a palabra en rima é rrém, mentres que o copista de $\mathbf{V}$ non copia texto. Cremos que máis cá letra do copista estamos ante unha letra "coidada" de man de Colocci. Podemos supoñer que, non sabendo que transcribir, se cadra, o copista advertiu o iesino do problema e el deulle unha solución. Non é inusual achar en B este tipo de intervencións do humanista. 
algo, mais si documentamos estruturas complexas en que o emisor (amante) é o que pide que o entendan: (vv. 1-4II, 97,1: Martin Soarez) "ca non quer Deus, nen vos, nen meu pecado / que me queirades per ren entender" (47,22: Fernan Rodriguez de Calheiros), malia que na segunda e terceira cobra desta cantiga a estrutura pase a ser primaria e o trobador lle diga a amante "E vos non queredes mentes meter" (similar a non queredes entender) ou "pois que nunca o quisestes saber". Do mesmo xeito que non documentamos a anadiplose querer como 'ter a vontade ou a determinación para' e querer 'amar ou ter cariño a alguén': entender non queredes que vos quero. O que si documentamos é o infinitivo creer como complemento directo do verbo querer (expresión "semellante" a entender non queredes) coa primeira das acepcións antes proposta: "pero mi-o vos non queredes creer" (43,18: Fernan Garcia Esgaravunha); "e me non queredes creer" (75,1: Joan Perez de Aboin) "Nonno queredes vos creer" (78, 9: Joan Soarez Somesso); "Senhor fremosa, pois me non queredes / creer a cuit' an que me ten Amor" (97,40: Martin Soarez); "que mi non queredes creer" (vv. 1-2II, 109,1: Nuno Rodriguez de Candarei). Como dixemos, nestes exemplos podemos ver que querer está asociado en amor a creer, nunca a entender nin a querer. A expresión 'crer que vos quero' aparece en Martin Soarez: "por Deus, creede ca vus quero ben" $(97,42)$. E expresións similares, pero con amar, en "Senhor fremosa, creede per mi / que vus amo ja mui de coraçon" $(101,12)$ ou actuando como obxecto directo a coita que sofre o amante nesta cantiga de Cogominho "E non mi creedes qual coita sofri / sempre por vos, nen quant' afan levei" (40,8). Michaëlis (1990, "Glossario": 34) recolle para entender, ademais dos significados xerais de "compreender, perceber", "reparar em alg." ou "ter conhecimento", a acepción de "ser amante, pretendente de alg.". Riquer (1975, II: 918) traduce o verso de Guilhem Magret "qu'en tal dompna mi fai amors entendre" como "pues amor me ha hecho enamorar de tal señora". Unha das nosas propostas (e afirmamos desde xa que pode ser errada ou un tanto forzada) pasaría por coordinar vosco falar coa expresión vós entender co significado de amar a dama, de ser o seu amante (o seu entendedor), como un paso posterior ao simple feito de lle declarar o seu amor. Lorenzo (1977, II: 556-557), rexistra “"comprender, darse cuenta, saber, oír $^{28}$ ' “cortejarse' 'entendimiento"”. Dinos tamén que tivo a acepción de 'pretender,

28 Deteñámonos agora na acepción 'oír', da cal nos advirte Lorenzo que pode confundirse con 'comprender'. Os exemplos que ofrece son "o que vos diziades entẽdiao eu moy bẽ" (dos Miragres) e "os rreys, poys que entenderon a messagen, rresponderonlle" (da Crónica Troyana). Poderiamos interpretar o sentido do verso como que o trobador non é quen de lle falar nin ela está disposta a escoitalo: vós entender? Neste sentido as palabras de Bec (1970, vol. I: 328-329), falando da forma entendeo nunha pasaxe da Demanda do Santo Graal, con que advirte que 'le sens de 'ouvir', qu'on trouve parfois dans la Demanda, est peut-être dû modèle français: ex. entendeu bem quanto disserom. Mais il est plus probable qu'il s'agit là d'une valeur sémantique sous-jacent; sa lexicalisation, en fr. même, ne date que du XVIIe s. (bien que la valeur d' 'entendre' soit attestée dès le XIe s.)", tamén poderían apoiar esta hipótese. 
amar, cortejar', acepción que, como a que ofrecía a filóloga alemá, lle acae ben a esta cantiga. Como exemplo ofrece o eminente investigador a CSM 130: "Quen entender quiser, entendedor / seja da Madre de Nostro Sennor. // Ca ela faz todo ben entender, / e entendendo nos faz connocer / Nostro Sennor e o seu ben aver / e que perçamos do demo pavor". O significado do verbo entender relacionado co amor móstrase con maior claridade no corpus de escarnio: "Elvira López, que mal vos sabedes / vós guardar sempre daqueste peon, / que pousa vosco, e á coraçon / de jazer vosqu', e vós non lh' entendedes" (MedDB2 70,19). Nesta cantiga de Don Denis poderiamos apreciar un xogo entre o bo goberno dun reino por parte do seu rei á hora de ter lucidez e de escoller sempre o mellor, e a boa elección da senhor á hora de se namorar (de entender, aquí empregado tamén en posición de rima) e de escoller o mellor candidato: "E pois sabedes entender / sempr' o melhor e escolher, / verdade vos quero dizer, / senhor, que servh' e servirei: / pois vos Deus atal foi fazer, / erades bõa pera rei" (MedDB2 25,79). Mesmo podemos achar o correlato nas cantigas de amigo; por exemplo nesta de Pedr' Amigo de Sevilha: "E ben vus poss' eu en salvo jurar / que outr' ome vivo non sab' amar / dereitamente, ca, per me provar, / vêheron outrus en min entender/ se poderiam de mi gaanhar; mays non poderon de mi ren aver" (MedDB2 116,34). Temos pois que razóns de índole paleográfica e temáticas fannos buscarlle unha interpretación á lectio ofrecida polo códice.

5. A lección do apógrafo transmite un verso hipómetro, que, malia ser correcto desde un punto de vista semántico, preferimos emendar: de quantas coufas no mundo fon. Michaëlis e Arias suplen a falta dunha sílaba no verso engadindo un $e$ a no: $[e]$ no. Poderiamos pensar que esta integración entraría en conflito co v. 21 onde temos un verso isómetro coa expresión no mundo. Porén, comprobamos que a alternancia dentro da produción dun mesmo trobador (igual que no caso de tal / atal) de formas do tipo no e eno non son estrañas mesmo dentro dunha mesma cantiga ${ }^{29}$, co único fin, cremos, de lograr a isometría dos versos e de conseguir un esquema estrófico completamente regular. Ademais deste feito, podemos lembrar a intertexualidade total do verso coa cantiga 73,3 de Joan Mendiz de Briteiros "de quantas cousas eno mundo som" (v. 4I; B 860-V 446); da 114,6 de Pai Gomez Charinho (v. 1I; A 256) e da 151,26 de Vasco Fernandez Praga de Sandin (v. 4II; A $3^{30}$-B 93). Expresións similares documéntanse na cantiga 9,11 de Afonso Sanchez "de quantas cousas son

29 Véxase por exemplo a cantiga 7,10 (B 377: "eno mundo" v. 6II / "no mundo" v. 2 III); 33, 1 (B 615bis-V 217: "no <meu> coraçon" vv. 4I, 4 III / "eno coraçon" v. 4II); 34,1 (B 923-V 511: "eno iferno" v. 4I / no iferno 1III); 43,9 (A 127-B 242: "no mundo" vv. 2,6I / eno mundo v. 4 I) ou 43,20 (B 229: "no seu coraçon" v. 4I / "eno seu coraçon" v. 4II).

30 Neste verso a partir de eno e ata mundo escribe o corrector identificado por Fernández Guiadanes (2010) como o amanuense que copia os folios $74 \mathrm{v}-79 \mathrm{r}$ de A. 
/ oje no mund' e..." (B 409-V 20: vv. 2-3III) ou 103,2 de Munio ou Nuno Fernandez de Mirapeixe “de quantas cousas no mund' á” (B 44: v. 2I). Entre os casos citados, pódese apreciar que en A 3 a expresión eno mundo é froito dunha corrección. Á vista do seguinte exemplo (A $171^{31}$ : f. 44r, col. a, 1. 2 ) no que vemos unha nota marxinal $e$ e a súa marca de inserción no verso entre o $-s$ de outras e o $n$ - de $n o$, indicando onde se debe inserir a nota marxinal, quizais poidamos concluír que en A 3 a corrección (neste caso introducida no texto) foi a mesma.

\section{x quintas outras no mix ion}

Estas explicacións lévannos a considerar que a emenda levada a cabo polo editores anteriores, a que nós nos acollemos, ten moitas posibilidades de ser a correcta.

9. A lección uiueR mostra un uso asistemático da letra maiúscula, é dicir, un uso ou forma nun contexto distinto ao de capital e poscapital, lugares onde se poden rexistrar na letra gótica. Segundo Varela (2005: 284), estas letras maiúsculas úsanse no Cancioneiro da Ajuda en posición final de palabra - case sempre en final de liñaou en inicio de palabra no medio da liña. No primeiro dos casos, Varela defende que, no códice de Ajuda, son usos de carácter residual e en todos eles a letra maiúscula é sempre a mesma: $<\mathrm{R}>$. O estudoso defende, pois, que o $<\mathrm{R}>$ en final de palabra tería, por un lado, un valor lingüístico-literario e, por outro, un valor codicográfico: este $<\mathrm{R}>$ indicaría fin de verso e fin de liña. Podemos supoñer, entón, que o copista, fiel ao seu orixinal, transladaba este tipo de letras.

13, 32. Michaëlis, Machado, Molteni e Arias conservan nas súas respectivas edicións a forma oesse por ouvesse, así como a forma oer (v. 32) por ouver.

Polo que respecta á forma oesse recollida neste verso, e segundo Carolina Michaëlis (1990, “Glosario”, I: 61, s.v. oesse), a “redução de ou a simples ô é possível, e realizouse por ex. em loar e oir. A queda de $v$ intervocálico em formas de um vocábulo tão usado como aver, seria todavia difícil de explicar. Para supormos houvesse apenas deficiente representação gráfica de ouu, acho os exemplos demasiadamente numerosos". Recentemente, Monteagudo (2008: 370-377) considerou as formas "oer / oera / oesse, formas do paradigma de aver". Constata o investigador que estas variantes só as rexistra en $\mathrm{B}$ e $\mathrm{V}$ e, na prosa documental, nunha carta de Sobrado de Trives. Ofrece unha lista de autores na produción dos cales se documentan estas formas nos apógrafos italianos, advertindo que a xulga completa malia non poder

31 Desmentido m'á 'qui un trobador $(79,13)$ de Johan Soarez Coelho, transmitida tamén en B 322, onde a lección que ofrece o códice é $e n o$. 
aseguralo, posto que partiu de edicións críticas (contrastadas cos manuscritos) e que algún dos editores puido apagar estas variantes. A súa afirmación non era desacertada. Como el ben di (2008: 377) "se se repasa a lista de textos que rexistran variantes de tipo oer, chama a atención a presenza de nomes do núcleo inicial, que son maioría, pero non pode deixar de constatarse que tamén figuran autores de cronoloxía máis adiantada (Martin Soarez, Johan Garcia de Guilhade, Gonçalo Eanes do Vinhal)". Coa súa argumentación, Monteagudo tentaba deixar claro que "a presenza destas variantes asocia Osoyro Anes cunha serie de autores do núcleo inicial ou do círculo inmediato de seguidores: Roy Gomez o Freyre, Fernan Rodriguez de Calleiros, Pero Garcia de Ambroa, Vasco Praga de Sandin, Johan Soayrez Somesso” (2008: 377).

Do noso estudo deste tipo de variantes nos cancioneiros trobadorescos constatamos os seguintes feitos:

a) Concordamos con Monteagudo en que A só presenta formas de tipo ouuer ${ }^{32}$.

b) Do primeiro punto infírese que, naqueles textos conservados en $\mathrm{B}$ e $\mathrm{V}$ (ou nun destes) e tamén en $\mathrm{A}$, comprobamos que onde os primeiros presentan as formas de tipo oer, o segundo ofrece sempre as formas "correctas" de tipo ouver, polo que os editores optaron por ofrecer as formas do códice ajudense, sen comentar a distinta lectio ofrecida polo códice da outra póla.

c) Concordamos tamén con el en que as formas de tipo oer / ouer/ ouuer alternan en B e V na produción dun mesmo trobador (como en B 49 e B 50, do autor que estamos estudando), malia que adoito estas últimas son amplamente maioritarias, e mesmo dentro dunha mesma cantiga (mais na súa forma átona, onde en principio diremos que nunca hai monotongación, fronte á tónica: ouve vs. oer en Gonçal' Eanes do Vinhal $(60,2)$ ou Pero d'Ambroa $(126,4)$.

d) Ademais de no elenco de autores que ofrece Monteagudo, achamos oer en Afonso Lopez de Baian (6,10: B 395-V 5) e Don Denis (25,15: B 544-V 147). $\mathrm{O}$ primeiro deles podería entrar no ámbito do grupo en que Monteagudo metía "Martin Soarez, Johan Garcia de Guilhade, Gonçalo Eanes do Vinhal", mais o segundo é un pouco posterior.

e) Monteagudo contempla en Osoir' Eanes o estadio intermedio ouer, entre o etimolóxico ouver e reducido oer, e na forma oui rexistrada en Gonçal' Eanes do Vinhal (60,7: V 1002, no v. 2I, fronte a ouualy no v. 2II: erro ou variantes gráficas ou fonéticas?). Nós, ademais do oui que localiza Monteagudo en Gonçal' Eanes do Vinhal, documentamos algúns outros exemplos de oue / oui como en Martin

32 Véxase o que se di no punto e). 
Soarez (97,23: A 43 ${ }^{33}$, v. 2IV moui én sabor), Afonso Fernandez Cebolhilha (3,7: B 404-V 15, v. 4I sempro oue) ou Estevan da Guarda (30,30: B 620-V 221, v. 2II senrpouy). Segundo el, poderiamos pensar que estas leccións serían unhas meras variantes gráficas de ouuer, posto que, como pode comprobarse no seu estudo sobre o Foral do Burgo de Caldelas e na Noticia de torto (2008: 186 e ss.), rexistra exemplos de tipo oue (forma átona) e ouer en lugar das formas etimolóxicas ouve e ouver, ademais de constatar para a representación gráfica do ditongo ou ata un total de cinco grafías diferentes: ou, ov, oc, o e au. Porén, conclúe (2008: 377), "tanto as variantes de tipo oer coma oui (de aver) (...) alertan sobre unha situación especial deste grupo de autores [refírese aos que presentan as variantes non etimolóxicas] algún chanzo da tradición manuscrita: tanto se se tratase de variantes puramente gráficas coma se representan (como xulgamos) variantes tamén fónicas, apuntan para un estadio scriptolingüístico e/ou lingüístico máis retrasado ca o manifestado en xeral polos manuscritos sobreviventes (incluído o Cancioneiro da Ajuda)". Preguntámonos: mesmo no caso de Don Denis e de Estevan da Guarda? A este respecto, nós, en B, rexistramos tres formas ouesse (25,71: B 717b; 75,2: B 674 e 157,41: B 605-606, todos casos do copista $a$ ) fronte á variante etimolóxica ouuesse que envía V (120, 276 e 208, respectivamente). Ante estes exemplos podemos preguntarnos en primeiro lugar cal era a lección que ofrecía o antecedente ${ }^{34}$. De ser a que envía $\mathrm{B}$, ouesse, debemos supoñer que o copista de $\mathrm{V}$ tiña competencia lingüística e corrixiu as formas? De ser correcta a lección de $\mathrm{V}$, debemos supoñer que o copista $a$ de B cometeu un erro por haplografía e eliminou un $u$ ou que o erro foi debido ao contexto en que aparecen estas formas (eu ouesse, outrouesse e ben ouesse, respectivamente), ou que tiña competencia lingüística polo que $o$ pasaba a ser a representación do ditongo ou? Que debemos editar se tomamos B como testemuño base?: colleremos a lección de $\mathrm{V}$ ou admitindo que existen formas con redución do ditongo editaremos a lección de B? A desaparición?/redución?/ monotongación? do $u$ dun titongo ou (dun au secundario) encontrámola tamén en formas como soub- e proug-: B 976 proguess (copista e) / V 563 prouguess (45,3: v. 1I); B 601 (copista a) sobestes / V 204 soubestes (25,80: v. 5II) 35; B 359 sobera (copista $e$ ) / A 208 soubesse (72,17: v. 2II); B 1359 sobel (copista $e$ ) / V 967 soubel (97,45: v. 1II); B 188a sobesse (copista $d$; 125,7: v. 3III) ou B 703 piu?guer

33 Michaëlis (1990 I: 93-94) edita “m’ ouv’ én sabor” sen facer ningunha referencia á forma do códice de Ajuda. Bertolucci (1992: 76) edita o mesmo que Michaëlis, e recolle erroneamente no aparato como lectura de A ouui én. Esta forma única no códice responderá a un erro por haplografía ou terá que ver con estoutras formas documentadas nos códices coloccianos?

$34 \mathrm{Se} \mathrm{B}$ fose testemuño único, teriamos tres casos máis en que testemunariamos a redución do ditongo ou a $o$.

35 Estes caso parece non dar lugar a dúbidas. O v. 5 é un verso de refrán, e isto quere dicir que na cobra un e tres ambos os dous códices transmiten soubestes. 
(copista $d$ ) / V 304 proguer. Cando temos dous testemuños (que supostamente parten dun antecedente común) podemos pensar que, para os catro primeiros casos, estamos ante un erro dos copistas de B e editar a forma con ou; tamén podemos pensar que as lecturas son tan correctas como as de $\mathrm{V}$, só que presentan a redución ou monotongación. Non obstante, se temos un testemuño único (B 188 a sobesse), ou dous, un cunha lectio de difícil lectura (B 703 p $u$ ? guer) e outro cunha clara lectura cun ditongo reducido ou monotongado (V 304 proguer), de admitirmos que o ditongo ou pode representarse por $o$, que debemos editar? Será suficiente para admitirmos que unha forma existiu que apareza unhas cantas veces nun único documento, nun cancioneiro, etc. e que siga leis fonéticas comprobadas (como sería a monotongación dun ditongo ou a redución gráfica dun ditongo?). As formas con epéntese consonántica derivadas de LAUDARE e AUDIRE, louvar e ouvir aparecen na lírica profana só en $\mathrm{B}$ e $\mathrm{V}$ de forma moi minoritaria (do mesmo xeito que moito/ moyto fronte a muito/muyto), mais sabemos que son formas existentes porque, en primeiro lugar, ademais de nestes cancioneiros rexístranse noutros moitos textos (malia que tamén de forma minoritaria) e, en segundo lugar, a variación das formas chega ata hoxe en día. Como ben afirma Monteagudo, o tema require dunha investigación máis polo miúdo, que nós tampouco imos levar a cabo nesta ocasión. É por todas estas dúbidas que preferimos deixar as formas transmitidas no códice. Quizais poidamos pensar que nos atopamos ante unha evolución fracasada, e que esteamos ante unha evolución semellante a de ouir> oír> ouvir ou louar> loar> louvar, froito da transposición da semiconsoante do grupo $-b w$ - e posterior caída do -b- ante o ditongo secundario - au-, feitos que ocasionarían a "redución dunha anómala secuencia de tres elementos vocálicos" (Ferreiro 1995: 66-67).

17. Arias edita: ja sei. O apógrafo italiano presenta, neste caso, unha lectura dubidosa; nós optamos pola forma $c a$ fronte a ja, como o resto dos editores da cantiga, porque, ademais de se adecuar mellor ao contexto, evitamos a repetición de $j a$, que aparece no inicio do verso seguinte (v. 18). No ms. non está claro que a lectura sexa ia nin $c a$. Ao que máis semella a grafía é a un erre; ademais confusións de $c$ po $t$ non son nada infrecuentes e de $c$ por $r$ ou $i$ tampouco, dependendo do grao de curvatura cara á esquerda que presente o $c$. Un claro caso de intertextualidade con este verso e o seguinte témolo nunha cantiga de Vasco Fernandez Praga de Sandin "que de vus atenda, ca sei / ca ja per vos non perderei / "gran coita do meu coraçon" (151,5: vv. 5-7I).

19. A lección do apógrafo italiano transmite un verso hipérmetro: Senõ por uos fenhor minha fe nẽbrar. Para restablecer a isometría do verso, Michaëlis e Arias editan mia senhor, lectura que nós tamén adoptamos, a pesar de que o apógrafo transmite claramente a forma fenhor minha. Fronte á reiterada e frecuentísima 
fórmula mia senhor (repetida no texto do freire en catro/cinco ocasións ${ }^{36}$ ) para facer mención ou invocar a muller amada, temos para este verso unha fórmula infrecuente e sospeitosa por supoñer a súa presenza no verso unha sílaba de máis. De feito, no corpus lírico galego-portugués tan só documentamos dúas cantigas que recollen a construción senhor minha: o escarnio de amor do trobador Afonso Sanchez, Conhocedes a donzela $(9,2)$ e a cantiga de malmonxada de Rodrigu' Eanes de Vasconcelos, Preguntei ũa dona eu como vos direi $(140,4)$. Co posesivo anteposto temos a cantiga atribuída a Roi Queimado Pois minha senhor me manda $\left(148,16^{37}\right)$. Polas razóns ata aquí expostas cremos que a forma do posesivo ten que ser a monosilábica mia.

22. A lección de B transmite un verso hipérmetro e semanticamente non aceptable: comauos querer e par d̄s feme dar. Michaëlis e Arias, para establecer a isometría do verso e o seu sentido, substitúen a forma verbal de infinitivo que reproduce B pola $1^{\text {a }}$ persoa do presente de indicativo, e editan: com'a vos quer'; e par Deus, se me dar, lectura que nós aceptamos. Machado, por outra parte, entende que o verso transmite un erro por substitución do copista, que transcribe $r$ por $n$, e edita: com a uos queren, $e$ par Deus, se me dar, cambiando o sentido do verso; é dicir, interpreta que o trobador non sabe querer ningunha outra cousa no mundo tanto como queren a súa señora; polo que a súa interpretación carece de sentido con respecto ao significado global da cobra. $\mathrm{O}$ erro quizais o cometeu o copista do códice, malia que tamén puidese estar xa no antecedente. Tendo en conta que no verso anterior aparece o infinitivo querer, o máis económico será que pensemos no común erro de salto de igual a igual.

27. A lección de B transmite un verso hipómetro: mal poys $p^{c}$ uos tāto mal me uen. Michaëlis e Arias emendan a falta dunha sílaba no verso engadindo a preposición de: mal, pois por vos tanto [de] mal me ven. Atendendo á collatio intratextual e en correspondencia co v. 25, "a que Deus tan muito de ben deu", xa teriamos un primeiro motivo polo que poder emendar cun grao alto de probabilidade. Tamén atendendo á collatio intertextual podemos ofrecer os seguintes exemplos en que documentamos usos similares de construcións intensificadoras con de: "O meu amigo a de mal assaz, / tant', amiga, que muito mal per é" (25,62: vv. 1-2I); "Pero faz m' el tanto de mal / quanto lh' eu nunca poderei / contar" (78,16: v. 1 III); “ca diz que lhi faze de mal assaz. / con seus cantares vai-o escarnir" (88,11: vv. 4-5I); "Perder-vus ei! que vus tan muito dura / de mal, com' eu por vos ei a sofrer, / e que non sei de vos aver rancura, / pero m' en coita fazedes viver, / e que vus ei por amor a

36 Cinco, se se admite a integración proposta para o v. 33 .

37 Nesta cantiga a expresión aparece no v. 1I-II (B 266: "Pois minha senhor me manda" e "Minha senhor me defende"). Sorprendentemente, Arias (2003: 846) edita o primeiro verso da cantiga, en contra da lección enviada polo códice, como "Pois mia senhor me manda", deixando o verso hipómetro. 
tẽer / quanto de mal me fazedes sofrer" (111,8); "Amiga, per ceos e quant'eu ey / de mal, mays nunca o já cearey" (116,22: fiinda); "mays ca mi fez, hu a primeyro vi, / tan muyto levar d' afam e de mal / que morrerey ..., hu non jaz al" (116,30: 3-5I); "poys que mi tanto de mal faz amor" (125,49: v. $5 \mathrm{IV})$; "mais pois per vos tan muito de mal ei" (125,51: v. 4III) ou "Non atendo de vos, por que me ven /muito de mal, mentr' eu viver, poren" (125,52: fiinda).

28. Michaëlis e Arias transforman a lección Quãdeu do códice en quant'eu.

33. Estamos ante un verso de difícil interpretación debido á lacuna que contén o apógrafo italiano: comoieu ey m [lac.] or teuer. Do material gráfico conservado (sete sílabas), e tendo en conta o esquema métrico, deducimos, por collatio intratextual, que faltan tres. Os editores propoñen distintas interpretacións. Michaëlis edita $[e$ por a]mor tever', a proposta dos Machado é $m$ [ays, mha senh]or. A lectura de Arias, igual ca a dos Machado, presenta un vocativo $m$ [ia senh]or e, para lograr a isometría do verso e conseguir un sentido axeitado, integra despois do vocativo a conxunción copulativa $[e]$. A lectura do filólogo galego xa fora avanzada por Nobiling que afirma "o aditamento $m$ [ha senh]or é assegurado pelo fato de que esta invocação parece duas vezes em cada estrofe. Só que o sentido e o metro ainda exigem a inserção da conjunção $e$, em relação à qual pode restar evidentemente a dúvida, se tem de ser inserida antes ou depois" (2007: 205).

34. Fazenda aparece recollido nos glosarios da lírica medieval (Lapa 1995, Nunes 1971, Michaëlis 1990) co significado de 'estado, situación, negocio', que é o que mellor se adapta ao contexto comentado. A cantiga de Johan Lopez de Ulhoa En que affan que oge viv'! e sei $(72,5)$ recolle e sintetiza moi ben na súa fiinda "Ca per quant' eu de mia fazenda sei, / o mellor é pera mi de morrer" o significado da cobra IV da cantiga do noso trobador.

Falando da cantiga de Johan Soarez Coelho Pero m'eu ei amigos, non ei niun amigo e do termo fazenda que nela aparece, Â. Correia afirma que:

os dois textos que apresentan mais afinidades com a cantiga em estudo são Non á ome que m'entenda de Fernan Rodriguez de Calheiros $(47,15)$ e Pois eu d'atal ventura, mia senhor de Rui Gomes. O primeiro texto apresenta, na primeira estrofe, os mesmos rimantes dos três primeiros versos da presente cantiga ("entenda", "prenda", "fazenda"), terminando todas as estrofes com a palabra-rima "fazenda". Os verbos que lhe são associados ("com' og' é"; "non sei mandado de", "Perece", "melhore") aproximam também ambas as situações discursivas. Quanto à segunda cantiga, o ponto de contacto é mais circunscrito e diz respeito ao que tem influência negativa sobre a "fazenda" do sujeito" (Correia 2001: 261). 
Unha vez máis a investigadora portuguesa volve dar conta da súa perspicacia ao mostrar estas intertextualidades entre estes autores. Teremos novamente aquí a presenza de Roi Gomes e Gonçal' Eanes de Novoa e a relación deste irmán de Osoir' Eanes co de Calheiros.

35. A lección de B presenta unha lacuna neste verso: nõ [lac.] greu. Michaëlis, Machado e Arias emendan este paso mediante a integración [me será], restablecendo, deste xeito, tanto o sentido como a isometría do verso. De novo o coidado con que parece traballar o copista $c$ levouno a sinalar con claridade cal era o anaco de texto que non nos pudo transmitir, por impericia ou porque o texto se presentaba borroso ou lacunoso no antecedente. Polo que respecta ó termo greu $^{38}$, e botando man do que denominamos collatio intratextual, parece evidente do confronto co verso anterior (que presenta rima en -eu) e do confronto co esquema rimático da cantiga que o elemento en rima debe ser este. A análise do esquema métrico permítenos certificar que o espazo deixado polo copista debería darlle cabida a tres sílabas. Malia que nos parece acertada a integración levada a cabo polo editores anteriores (lectura que parte de Michaëlis), consideramos oportuno ver os contextos en que aparece greu para poder certificar con máis seguridade a integración: "dizede-mi-o, e non vos seja greu” (2,3: v. 3IV); “e, poys a vós aquest' é greu” (12,4: v. 5I); "greu vos seri', a meu cuydar" (12,4: vv. 5-6I); “e por aquesto m' é greu (25,9: v. 7I); “que des oi mais, pero m'é greu" (25,64: v. 4II); "e dizede-lhi, pero me foi greu” (25,82: v. 3I); "Ca de me matar amor nom m' é greu” (25,108: v. 1III); “e, mha senhor, pero que m'é muy greu" (73,3: v. 5III); "Muyto lh' é greu" (87,16: v. 7III); "Martin Soarez, a mi non é greu" (97,2: v. 1IV); "de se tornar; e foi-lhi greu" (97,28: v. 5V); “e, pero que sey que lh' este muy greu" (100,3: v. 5II) e "Que mi-ante de vos era greu" $(157,15$ : v. 1V). Os datos que podemos extraer desta collatio intertextual é que a construción en que participa o provenzalismo parece responder sempre (en negativo ou afirmativo) a un pronome persoal mais o verbo ser mais greu (modificado mediante o adverbio muy ou non). O pronome que parece pedir a oración é o de obxecto directo de primeira persoa me. Polo que respecta ao verbo ser necesitamos unha forma bisílaba que encaixe na consecutio temporum: neste caso cremos que só a forma de futuro será ten correlación co prazer$m i-a ́$ do verso seguinte. Poderiamos pensar, entón, en editar esta última forma como prazer- $m$ '-ia, forma que tamén tería sentido, mais desbotámola tendo en conta que esta lectura requiriría dun condicional sería no verso anterior, forma trisílaba que faria que reconstruísemos un verso hipérmetro.

38 O termo é un provenzalismo que procede do latín popular GREVE, que substituía a forma grave por analoxía co seu antónimo leve. 
37. Ao respecto da lectura de Michaëlis ía vos fazer (tamén adoptada por Arias) di Nobiling (2007:205) "o manuscrito tem hi auos fazer, sendo que com hi auos se quer dizer sem dúvida $i$ a vos. O fazer rima con o poder da linha seguinte; mas como a fiinda que começa aquí repete rimas da estrofe precedente e como precisamos uma rima ęr, e não em ẹr, o fazer é com certeza grafia equivocada de fezer".

39. De novo un verso de difícil interpretación, como se aprecia nas distintas lecturas que ofrecen os editores. Michaëlis edita: e vos nembrar (o qu(e) é ben lheu); Machado: nenbra que uos a ben lheu; mentres que Nobiling (2007: 205) e Arias: nembrarvos á ben lheu. Optamos pola lectura de Nobiling, xa que consideramos coma el que a lectio que ofrece o apógrafo italiano (que xa podería estar no antecedente), nébraqu9, presenta un erro por substitución do copista, que interpreta un erre longo coma un 'q' pola atracción do ' $u$ ' ao estar perante unha cadea de palabras en escrita continua. Por esta razón, entendemos que estamos ante unha construción perifrástica de futuro, é dicir, nembrar-vos-á, co significado de 'lembrarédesvos', con que establecemos o sentido do verso.

Ben lheu é unha locución adverbial que presenta o significado de 'axiña, moi facilmente'. Esta expresión é empregada por outros seis trobadores (Alfonso X, "se aquesto sofredes ben lheu / querran a outr' assi furtá-lo seu” 18,41); Fernan Paez de Tamallancos, ("e dira-vo-lo ben lheu quen vos en cos / vir tira-los nadigões apos vós" 46,4); Johan Baveca, ("E quen vos pois vir la saia molhada / ben lheu terrá que é con escasseza" 64,10); Johan Nunez Camanes, ("Podedes vos nembrar bem leu / de mim que sofro muito mal" 74,3); Pero de Bardia, ("mui fremosa, meu amigo ben leu / querrá falar migo e non querrei eu" 122,5); Osior'Anes, ("e se vos end' al cuidades, / ben leu tort' én prenderei!" 111,3)) e, segundo H. Monteagudo (2008: 377-378), resulta descoñecida no resto de textos galego-portugueses. Por outra banda, o adverbio lheu é considerado un provenzalismo introducido na linguaxe trobadoresca que non arraigou noutros rexistros do galego-portugués. Segundo García-Sabell (1991: 203-205), rexístrase nos cancioneiros con dúas variantes: leu, empregada tan só por Osoir'Anes, e lheu para todas as demais ocorrencias. GarcíaSabell defende que a variedade que presenta consoante palatal chegaría a través do catalán lleu. O termo non se conservou no galego actual, mais si no portugués na expresión ao leu (leo). Repárese, ademais, na rima antitética sobre os termos provenzais greu (v. 35) e lheu (v. 39). A expresión, ademais de na lírica profana e nas $C S M^{39}$, achámola na tradución portuguesa do Foro Real de Alfonso X o Sabio:

39 CSM 69, cobra 14: "Entonçe diss' el conde muit' agynna: / "M' ide polo que fez a meezinna, / ca ben leu é maestre de Meçinna, /ou de Salerna, a çizillãa". / Santa Maria os enfermos sãa..." (To 54 ben leu, E 69 ben leu, T 69 ben 1leu); CSM 97, cobra 3: "Demais un rico pano y deu / na eigreja e fezo-sse seu / ome da Virgen, com' aprix eu; / e est' avia nome Mateu, / e ben leu / pode-1-an en cas del Rei 
Porque acaeçe muytas uees que ante que os fruytos seyan tolheytos das herdades morre o marido ou ben leu fica o marido e morre a molher, porende estabelecemos que se os fruytos ficã e parecë ena herdade aa sazõ da morte, que se partã per meo o viuo e os erdeyros do morto; e se nõ parecerë, aya os fruytos ou aia por herdade e d é as mixões que forë feytas a quë a laurou e esto seya se a rayz for uinha ou arbores (Ferreira 1987: 207).

E se peruentura o souber ella ca era cassado cû outra, os fillos della nõ seyã erdeyros e seyã ambos metudos en poder da molher primeyra cû todo seu auer, se fillos doutro marido non auia ou ben leu legitimos que leuen toda sa boa (e) e de sa madre". Livro III, título VI (Ferreira 1987: 216).

40. Á hora de transcribir, moitas veces non resulta nada doado desingrir os trazos verticais e as unións superiores e inferiores que dan lugar a certas letras con paus, como as cadeas mui, nu, min, etc. Neste caso non hai dúbida de que o copista cometeu un erro por incomprensión do antecedente e reproduce como demuj un suposto demin.

\subsection{Oimais non sei eu, mia senhor}

B 50, ff. 16r, col. b - 16v, col. a

Tavani, 149, 1

Oimais non sei eu, mia senhor, ren per que eu possa perder coita, nos dias que viver, pois vós non avedes sabor

5 que vos eu diga nulha ren de quanto mal me por vós vén.

E pesa-vos de vos amar eu, e non m' ei end' a quitar,

en tanto com' eu vi[vo] for,

10 ca non ei poder d' al fazer, ca se d' al ouvesse poder, aver-vos-ia desamor assi como vos ei gran ben

connocer. / A Virgen sempr' acorrer, acorrer...” (To VIII ben leu, E 97 ben leu, T 97 ben lleu); CSM 389, cobra 6: "Con el alá offreçessen; / ca non tiinnam dinneyros // que partir de ssi podessem, / nen ovellas nen carneiros // dos seus dar non y queriam, / ca os santos son arteiros; //mais dar-1l-ia dous capões / ou ben leu dous ansarin[n]os. // A que pera parayso / irmos nos mostra caminnos..." (T 389 ben leu). 
a querer sen grad', e por én
15 me pessa, porque com[e]çar

foi convosc', a vosso pesar.

E pois a vós pesa, de pran, de que convosco comecei, guisad' é que non perderei,

20 sen morrer, coita nen afan por vós, senhor, pois me non val contra vós serviço, nen al que vos faça, pero que-quer vos sofrerei mentr' eu poder

25 viver. Mais non me leixarán os desejos que de vós ei, que eu, senhor, non poder[ei] sofrer; assi me coitarán por vós, que me queredes mal

30 porque vos amo: é, pois atal ventura ei eu, mui mester de morrer, pois a vós prouguer.

Edición crítica de Michaëlis (1990: 334; 667-668).

Edición semidiplomática e interpretativa Molteni (1880: 24; 15-16) e Machado (19491964, I: 24; 66-67).

9. vivo] uy om. B 15. começar] comçar B 18. comecei] comoçej B 19. perderei] perderey $\mathrm{B}$

1. Oy; maýs; nō; fey; mha 3. coýta; n9; uiuer 4. poys; uos; aue des 5. queu9 6. uos; uen 7. epefau9; deu9 8. enonmeý; endaquytaR 10. nō; eý; 11. ouuefle; $\operatorname{pod}^{\mathrm{f}}$ 12. au ${ }^{\mathrm{f}} \mathrm{u} 9$ hia 13. affy; comou9; ey; g'm 14. aq̄rer; fè; $\mathrm{g}^{\mathrm{i}} \mathrm{de}$; porē 15. $\mathrm{p}^{\mathrm{r}} \overline{\mathrm{q}}$ 16. foý; cōuofca; uoflo; pefar 17. poys; auos; prā 18. $\overline{\mathrm{q}}$; cō uofco 19. gifade 20. fen; coýta; nē; affan 21. fenhor; poyfme; nō; ual 22. 9; uos; fuiço 23. $\mathrm{q}^{-}$; u9; po; $\overline{\mathrm{q}} \overline{\mathrm{q}} \mathrm{r}$ 24. u9; fof?frerey; ment ${ }^{\S} \mathrm{u}$ 25. Uiuer; mays; nōme; leixarā 26. defei9; $\bar{q}$; deuos; eý 27. $\bar{q}$; fenhr; nō 28. coytaram 29. $\mathrm{p}^{\mathrm{r}}$; uos; $\overline{\mathrm{q}}$; $\overline{\mathrm{q}}$ redes 30. $\mathrm{p}^{\mathrm{r}} \overline{\mathrm{q} u}$; ; poys 31. uētura; ey; muj; melt $\mathrm{f}^{\mathrm{f}}$ 32. morr $^{\mathrm{f}}$; poys; auos; pug ${ }^{\text {I }}$ 


\section{Sinopse retórico-formal}

Cantiga de amor, de mestría que consta de catro cobras dobras de 8 versos, todos eles octosílabos agudos. O número de esquema métrico que lle outorga Tavani ao texto é 168:7 (8a8b8b8a8c8c8d8d).

\section{Notas aos versos}

5. O pronome indefinido nulha, que deriva da forma latina NūLlA, co significado de 'ningunha', documéntase especialmente na lingua da poesía trobadoresca, mais tamén se rexistra esporadicamente na prosa. Segundo Azevedo (1986: 704), estas formas "têm sido interpretadas como provençalismos ou castelhanismos", e insiste que "é provável que $l \mathrm{~h}$ represente a lateral alveolar, sendo, portanto, nulho, nulha formas genuinamente galego-portuguesas". Un estudo pormenorizado desta expresión e outras similares pode verse en Monteagudo (2008: 269-312), malia que, como no caso de ben lheu, debamos ter coidado con algunhas das súas afirmacións: "a locución nulla ren, documentada nos textos latino-galaicos desde o século XI e que circula abundantemente nos textos en galego do século XIII, simplemente non existe en castelán [a cursiva é nosa]" (2008: 311). No CORDE achamos os seguintes exemplos: "uen vedar que ninguno de las partes non lis digan nulla ren a los combatedores (c. 1250, Anónimo, Fuero de Tudela); "quien de bueys ode uacas coyier pan. En lla uüla nulla ren non lles den" (c. 1252, Anónimo, Fuero de Ledesma); "su uasalla su desde que passo su marido, e non de nulla ren" (c. 1252, Anónimo Fuero de Ledesma); "Mugieres de porteros non den aliujz nulla ren del sal que uendieren" (c. 1252, Anónimo, Fuero de Ledesma); "endera njn por pecho nin por nulla parada nin por nulla ren. Delos que sse meten so otro senorio" (c. 1252, Anónimo, Fuero de Ledesma; "precio plogo anos et auos et del precio tras vos nulla ren non remaso et simaes uai la quarta desta" (1258, Anónimo, Dominga Iohaniz vende parte de una casa en Oviedo); "orabetinos onde somos bian pagados e non remanece nulla ren por dar ca todo ia conplido" (1239, Anónimo, Carta de venta); "nas coitas deste mundo ben quiser soffrer. Per nulla ren que ll' o Emperador dissesse, nunca quis" (c. 1284, Anónimo, Traducción de las Cantigas de Santa María; "ant' o Emperador aque-a ven; mas o demo enton per nulla ren nona connoceu nen lle disse nada" (c. 1284, Anónimo, Traducción de las Cantigas de Santa María); "vidieron que de nuevo nulla ren non levaron, los paños que trasquieron esso" (c. 1236, Gonzalo de Berceo, Vida de Santo Domingo de Silos); "castillos e aldeas e otras heredades, nulla ren non robava en ningunos lugares" (1240-1250, Anónimo, Libro de Alexandre).

8. A forma verbal quitar é o infinitivo que depende da perífrase aver $a+$ infinitivo. Os glosarios (Lapa 1995: 369, s.v. "quitar"; Lorenzo 1977: 1095, s.v. "quitar"; 
Michaëlis, 1990, I, “Glossário": 76, s.v. “quitar”) recollen as acepcións “deixar, liberar, eximir dunha obriga, separar, impedir" como posibles valores semánticos da forma quitar na lingua medieval. Decantámonos pola acepción de "liberar" neste contexto. Non obstante, Lorenzo (1977: 1095) sinala a orixe dubidosa deste termo, xa que, segundo este, deriva do latín QUIĒTĀRE ou ben do adxectivo QUITO, aínda que, para el, "no está claro el punto de partida".

A perífrase aver $a+$ infinitivo ten o sentido de obrigatoriedade, neste caso por parte do suxeito, e adquire matiz de futuridade.

9. De novo o copista deixa un espazo para indicar unha lacuna textual, feito que nos advirte dunha lectura incomprensible ou dun treito borroso ou afectado por un burato ou unha humidade. Temos pois que o apógrafo italiano transmite un verso hipómetro carente de sentido: En tanto comeu uy ... for. Michaëlis edita Entanto com 'eu vivo for' e, pola súa parte, Machado Entanto com eu uy[uo] for.

14. O conglomerado "grade" aparece escrito como gide, cunha abreviatura típica de ui rexistrada, entre outros, no v. 19 gifade "guisade". O normal sería que aparecese o representante da abreviatura visigótica que semella un $a$ aberto por arriba.

15. A lección do apógrafo italiano, na forma que nos chegou, transmite un verso hipómetro e carente de sentido: $m e$ pe $\iint a p^{c} \bar{q}$ comçar. As posibilidades semánticas do verso parecen estar esgotadas coas lecturas achegadas por cada un dos editores. Así, Michaëlis edita: me pesa, porque começar; e Machado: me pesa, porque com [e] çar. Nótese o erro por omisión do copista, que non transcribiu a vogal $e$ na forma verbal começar.

Malia que a forma pessa ten como étimo PENSARE e o seu resultado debería ser a fricativa alveolar sonora (presente no v. 7 e 17), mantemos a lección xorda transmitida polo manuscrito.

18. A lección de $\mathrm{B}$, tal e como nos chegou, transmite un verso carente de sentido: de $\bar{q}$ co uofco comoçej. Nótese o erro por substitución do copista, que transcribe $o$ por $e$ na forma verbal comecei; este erro é frecuente tamén en $\mathrm{V}$, tal e como recolle Monaci na súa táboa (1880: XVIII). Tanto Michaëlis como Machado emendan este erro e editan nas súas respectivas edicións: de que con vosco comecei, e de que conuosco começej.

20. Tomado do provenzal afan, derivado de afanar, o termo afan presenta un dobre significado, tal e como recollen os diferentes glosarios e dicionarios galegoportugueses (Lorenzo 1977: 43-44, s.v. "afam"; Michaëlis 1990, I, "Glossário": 3, s.v. "afan, afam"; Lapa 1995: 290, s.v. "afan": por un lado, un significado de 
sintomática física, equivalente a 'fatiga, traballo, esforzo, molestia', e, por outro, un de tipo psicolóxico, sinónimo de 'pena, tormento, angustia, dor'. Na lírica galegoportuguesa o termo está documentado desde os primeiros textos -en concreto, o rexistro máis antigo de afan está nas cantigas da chamada segunda xeración trobadoresca (1200-1240)-, e aparece asociado, na maioría das ocasións, a outros vocábulos que configuran o campo sémico da coita de amor, sobre todo, coita e mal, como se observa neste verso. Domínguez Carregal (2009: 163-64), apunta que o termo "é usado exclusivamente cun significado específico, de carácter metafórico, moi relacionado co sentimento de coita amorosa [...]. A especialización do termo no campo léxico da coita amorosa xa desde os primeiros trobadores dálle ao termo unha forza especial, un valor central no código poético do sufrimento amoroso, e acompañará o xénero poético trobadoresco na súa difusión”.

21. O pronome persoal tónico vós aparece neste verso escrito co alógrafo angular $v$ fronte ao resto das ocorrencias onde encontramos o alógrafo curvo $u$. Diferénciase dun $b$ - (B 49) polo primeiro astil ascendente fusiforme inclinado cara á esquerda.

23. O pronome indefinido que-quer presenta o significado de "calquera cousa, sexa o que fose, o que". Segundo Ferreiro (1995: 266), trátase dun indefinido arcaico procedente da aglutinación 'que + quer', que se perdeu co paso do tempo entre o galego-portugués e o galego moderno.

24. A transmisión do termo nesta cantiga mostra unha "posible" variatio gráfica, na súa vertente etimolóxica neste verso soffrerey (dicimos "posible" porque o primeiro efe non está claro: ou por incomprensión do antígrafo ou por inacabamento da parte superior da grafía), mais non no v. 28, onde se rexistra claramente sofrer.

27. A lección do apógrafo italiano transmite un verso hipómetro: $\bar{q}$ eu fenh $h^{r}$ nō poder. $\mathrm{O}$ verso, tal e como nos chegou, carece de sentido. Nótese o erro por omisión do copista deste cancioneiro ou do do seu antecedente que non transcribiu a forma de $1^{\mathrm{a}}$ persoa de singular do futuro de indicativo (poderei), senón a forma do infinitivo ou do futuro de subxuntivo (poder). A emenda lévase a cabo por collatio intratextual, posto que seguindo o esquema rimático da cantiga só é posible esta rima.

30. A lección de $\mathrm{B}$, na forma que nos chegou, transmite un verso que fai necesaria a sinalefa entre amo e a conxunción copulativa $e$ ou ben podemos pensar no uso con valor métrico dos dous pares tal/atal. Michaëlis, na súa edición propón a seguinte lectura e edita: porque vus am(o); e pois atal. Unha busca simple pola palabra ventura permítenos constatar que con este termo tanto se usa tal coma atal, polo que sería factible tanto un termo coma o outro. Agora ben, unha busca da primeira 
persoa do presente de indicativo do verbo amar e da conxunción copulativa $e$, fainos constatar que en todas as ocorrencias documentadas no corpus profano ou se dá a elisión vocálica ou é necesaria unha "suposta" sinalefa como neste caso.

31. Michaëlis substitúe a lección do ms. uètura ey muj; me $t^{\S}$ por ventura ei, ei mui mester. A lectura destes versos, que non altera a lección do apógrafo, foinos ofrecida polo profesor Manuel Ferreiro.

\section{Referencias Bibliográficas}

Alvar, C. (1978): Textos trovadorescos sobre España y Portugal (Madrid: Cupsa Editorial).

Arias Freixedo, X. B. (2003): Antoloxía da lírica galego-portuguesa (Vigo: Xerais).

Avalle, D. S. (1960): Poesie / Peire Vidal (Milano: R. Ricciardi).

Ayala Martínez, C. de (2003): Las órdenes militares hispánicas en la Edad Media : siglos XII-XV (Madrid: Marcial Pons : Latorre Literaria).

Azevedo Maia, C. de (1986): História do galego-portugués. Estado lingüístico da Galiza e do Noroeste de Portugal desde o século XIII ao século XIV (Com referencia à situação do galego moderno) (Coimbra: Fundação Calouste Gulbenkian).

Barbieri, M. (1993): "Roi Gomez, o Freire”, en DLMGP, 584-585.

Bec, P. (1970): Manuel practique de philologie romane, 4 vols. (Paris: Éditions A. \& J. Picard).

Beltran, V. (1995): A cantiga de amor (Vigo: Xerais).

Bertolucci Pizzorusso, V. (1992): As poesías de Martin Soares (Vigo: Galaxia).

Boullón Agrelo, A. I. (1999): Antroponimia medieval galega (ss. VIII-XII), Patronymica Romanica (Max Niemeyer Verlag, Tübingen).

Brea, M. (2005): “Que gran coita d'endurar. Anotacións sobre o uso lírico de endurar", en Boullón Agrelo, A. I. / Couceiro Pérez, X. L. / Fernández Rei, F. (eds.): As tebras alumeadas: Estudos filolóxicos ofrecidos en homenaxe a Ramón Lourenzo, 527:539 (Santiago de Compostela: Universidade de Santiago de Compostela / Servicio de Publicacións e Intercambio Científico).

Cappelli, A. (1995): Dizionario di abbreviature latine ed italiane: usate nelle carte e codici specialmente del Medio-Evo riprodotte con oltre 14000 segni incisi (Milano: Ulrico Hoepli). 
$C S M=$ Mettmann, W. (ed.) (1959-1972): Alfonso X, Cantigas de Santa María, 3vols. (Coimbra: Universidade de Coimbra).

CORDE: REAL ACADEMIA ESPAÑOLA: Banco de datos (CORDE) [en línea]. Corpus diacrónico del español. Dispoñible en http://www.rae.es [consult. 31/01/2011].

Correia, Â. (1995): “O sistema das coblas doblas na lírica galego-portuguesa”, en Paredes, J. (ed.): Medioevo y Literatura. Actas del V Congreso de la Asociación Hispánica de Literatura Medieval (Granada, 27 septiembre-1 octubre 1993): II, 75-90 (Granada: Universidad de Granada).

Correia, Â. (2001): As cantigas de D. Joam Soares Coelho e o "ciclo da ama" [Dissertação de doutoramento em Literatura Portuguesa] (Lisboa: Faculdade de Letras da Universidade de Lisboa).

Cruz Coelho, M. H. da (1988): O Mosteiro de Arouca : do século X au século XIII (Arouca: Cámara Municipal, Real Irmandade da Rainha Santa Mafalda).

DLMGP = Lanciani, G. / Tavani G. (orgs.) (1993): Dicionário de Literatura Medieval Galega e Portuguesa (Lisboa: Ed. Caminho).

Domínguez Carregal, A. A. (2009): "O uso de afan na lírica galego-portuguesa", en Brea, M. (ed.): Pola melhor dona de quantas fez nostro senhor. Homenaxe á profesora Giulia Lanciani, 153-168 (Santiago de Compostela: Xunta de Galicia / Centro Ramón Piñeiro para a Investigación en Humanidades).

Fernández Guiadanes, A. (2010): "Particularidades gráficas e de impaxinación do folio 79r do Cancioneiro da Ajuda: o seu copista é ¿un copista corrector?”, en Arbor Aldea, M. / Fernández Guiadanes, A. (eds.): Estudos de edición crítica e lírica galego-portuguesa. Anexo 67 de Verba, 163-194: (Santiago de Compostela: Universidade de Santiago de Compostela / Servizo de Publicacións e Intercambio Científico).

Fernández Guiadanes, A. / Río Riande del, G. [no prelo]: "Hacia una emendatio legítima: la collatio intra e intertextual en la edición de la lírica profana gallego-portuguesa", Incipit XXX.

Ferrari, A. (1979): "Formazione e struttura del Canzoniere Portoghese della Biblioteca Nazionale di Lisbona (Cod. 10991: Colocci-Brancuti). Premesse codicologiche alla critica del testo (Materiali e note problematiche)", Arquivos do Centro Cultural Português XIV, 27-142.

Ferreira, J. de Azevedo (1987): Afonso X. Foro Real (Lisboa: Instituto Nacional de Investigação Científica). 
Ferreiro, M. (1995): Gramática histórica galega. I. Fonética e Morfosintaxe (Santiago de Compostela: Edicións Laiovento).

Ferreiro, M. / Martínez Pereiro, C. P. / Tato Fontaíña, L. (eds.) (2007): Normas de edición para a poesía trobadoresca galego-portuguesa medieval (A Coruña: Servizo de Publicacións da UDC).

Figueiredo J. A de (2003) [reimp. facs. da ed. de 1800]: Nova Historia da Militar Orden de Malta e dos Senhores Grão-Priores della em Portugal, 3vols. (Lisboa: Servicios gráficos Edinova).

Frateschi Vieira, Y. (1999): En cas dona Maior: os trovadores e a corte senhorial galega no século XIII (Santiago de Compostela: Laiovento).

García-Sabell Tormo, T. (1991): Léxico francés nos cancioneiros galegoportugueses: revisión crítica (Vigo: Editorial Galaxia).

Gonçalves, E. (1976): "La Tavola colocciana. Autori portoghesi”, Arquivos do Centro Cultural Português, X: 387-448.

Gonçalves, E. (1994): “O sistema das rubricas atributivas e explicativas nos cancioneiros trovadorescos galego-portugueses", en Lorenzo, R. (ed.): Actas do XIX Congreso Internacional de Lingüística e Filoloxía Románicas. IV, 979-990 (A Coruña: Fundación Pedro Barrié de la Maza, Conde de Fenosa).

LPGP = Brea, M. (coord.) (1996): Lírica profana galego-portuguesa. Corpus completo das cantigas medievais, con estudio biográfico, análise retórica e bibliografia especifica, realizado por F. Magán Abelleira, I. Rodiño Caramés, M. C. Rodríguez Castaño e X. X. Ron Fernández, coa colaboración de A. Fernández Guiadanes e M. C. Vázquez Pacho, 2 vols. (Santiago de Compostela: Xunta de Galicia / Centro de Investigacións Lingüísticas e Literarias "Ramón Piñeiro").

Lapa, M. Rodrigues (1995): Cantigas d'escarnho e de mal dizer dos cancioneiros medievais galego-portugueses. Edição crítica e vocabulário (Vigo, Lisboa: Ir Indo Edicións, Edições João Sá da Costa).

Lorenzo, R. (1977): La traducción gallega de la Crónica General y de la Crónica de Castilla, 2 vols. (Ourense: Instituto de Estudios Orensanos "Padre Feijoo").

MedDB: Base de datos da Lírica Profana Galego-Portuguesa (MedDB), versión 2.0. [en línea], Centro Ramón Piñeiro para a Investigación en Humanidades. Dispoñible en http://www.cirp.es [consult. 21/02/2011].

Machado, J. P. / Paxeco, E. (1949-1964), Cancioneiro da Biblioteca Nacional, antigo Colocci-Brancuti (Lisboa). 
Mattoso, J. / Sousa, A. de (1993): História de portugal. A monarquia feudal (10961480) (Lisboa: Editorial Estampa).

Menéndez Pidal, R. (1964): Cantar de Mio Cid. Texto, gramática y vocabulario, 3 vols. (Madrid: Espasa Calpe).

Michaëlis de Vasconcellos, C. (1990): Cancioneiro da Ajuda, 2 vols. (Lisboa: Imprensa Nacional-Casa da Moeda).

Millares Carlo, A. (1983); Tratado de Paleografía Española, 3 vols. (Madrid: Espasa Calpe).

Miranda, J. Ribeiro (2004): Aurs mesclatz ab argen. Sobre a primeira geração de trovadores galego-portugueses (Porto: Edições Guarecer).

Molteni, E. (1880): Il Canzoniere portoghese Colocci-Brancuti (Halle: Max Niemeyer).

Monaci, E. (1880): Il Canzoniere Portoghese della Biblioteca Vaticana (Halle: Max Niemeyer Editore).

Monteagudo, H. (2008): Letras primeiras. O Foral do Burgo de Caldelas, os primordios da lírica trobadoresca e a emerxencia do galego escrito (A Coruña: Fundación Pedro Barrié de la Maza).

Nobiling, O. (2007): As cantigas de D. Joan Garcia de Guilhade e Estudos dispersos [edición de Yara Frteschi Vieira] (Niterói: Xunta de Galicia / EduFF).

Nunes, J. J. (1971): Cantigas d'amor dos trovadores galego-portugueses. Edição crítica acompanhada de introdução, comentário, variantes e glossário (New York: Kraus Reprint).

Rades y Andrada, F. de (1980): Crónica de las tres Ordenes de Santiago, Calatrava y Alcántara: con un estudio sobre "la obra histórica de Rades y Andrada" de Derek W. Lomas (Barcelona: El Albir).

Resende de Oliveira, A. (1994): Depois do espectáculo trovadoresco. A estrutura dos cancioneiros peninsulares e as recolhas dos séculos XIII e XIV (Lisboa: Edições Colibri).

Riquer, M. de (1975): Los trovadores: historia literaria y textos (Barcelona: Planeta).

Rodríguez, J. L. (1980): El Cancionero de Joan Airas de Santiago. Edición y estudio. Anexo 12 de Verba (Santiago de Compostela: Universidade de Santiago de Compostela / Servizo de Publicacións e Intercambio Científico). 
Rodríguez, J. L. (1988): “Os nomes dos trovadores. Algumhas anotacons para umha fixacom possível”, en Beltrán, V. (ed.): Actas del I congreso de la asociación hispánica de literatura medieval, Santiago de Compostela, 2 al 6 de Diciembre de 1985, 523-538 (Barcelona: P.P.U).

Souto Cabo, J. A. [no prelo]: "Intersecção escritural discursiva no primeiro documento romance da Galiza. A cessão do mosteiro de Arneses à condessa $D^{a}$ Sancha (1222)".

Varela, X. (2005): "Os usos das letras maiúsculas no Cancioneiro da Ajuda", en Boullón Agrelo, A. I. / Couceiro Pérez, X. L. / Fernández Rei, F. (eds.), As tebras alumeadas. Estudos filolóxicos ofrecidos en homenaxe a Ramón Lorenzo, 275-288 (Santiago de Compostela: Universidade de Santiago de Compostela / Servicio de Publicacións e Intercambio Científico).

Viejo Fernández J. (1998): La onomástica asturiana bajomedieval. Nombres de persona y procedimientos denominativos en Asturias de los siglos XIII al XV (Tübingen: Patronymica Romanica / Max Niemeyer Verlag). 